\title{
Reactivation of wild-type and mutant p53 by tryptophanol- derived oxazoloisoindolinone SLMP53-1, a novel anticancer small-molecule
}

\author{
Joana Soares ${ }^{1,2}$, Liliana Raimundo ${ }^{1,2}$, Nuno A.L. Pereira ${ }^{4}$, Ângelo Monteiro4, Sara \\ Gomes $^{1,2}$, Cláudia Bessa ${ }^{1,2}$, Clara Pereira1,2, Glória Queiroz ${ }^{3}$, Alessandra Bisio ${ }^{5}$, \\ João Fernandes ${ }^{6}$, Célia Gomes ${ }^{6}$, Flávio Reis ${ }^{6}$, Jorge Gonçalves ${ }^{3}$, Alberto Inga ${ }^{5}$, \\ Maria M.M. Santos ${ }^{4}$, Lucília Saraiva ${ }^{1,2}$ \\ ${ }^{1}$ UCIBIO/REQUIMTE, Universidade do Porto, Porto, Portugal \\ 2Laboratório de Microbiologia, Departamento de Ciências Biológicas, Faculdade de Farmácia, Universidade do Porto, \\ Porto, Portugal \\ 3Laboratório de Farmacologia, Departamento de Ciências do Medicamento, Faculdade de Farmácia, Universidade do Porto, \\ Porto, Portugal \\ ${ }^{\mathbf{4}}$ Research Institute for Medicines (iMed.ULisboa), Faculty of Pharmacy, Universidade de Lisboa, Lisboa, Portugal \\ ${ }^{5} \mathrm{CIBIO}$, Centre for Integrative Biology, Laboratory of Transcriptional Networks, University of Trento, Trento, Italy \\ Gaboratório de Farmacologia e Terapêutica Experimental, IBILI, Faculdade de Medicina, Universidade de Coimbra, \\ Coimbra, Portugal
}

Correspondence to: Maria M.M. Santos, e-mail: mariasantos@ff.ulisboa.pt

Lucília Saraiva, e-mail: lucilia.saraiva@ff.up.pt

Keywords: Tumor, p53, mutant, tryptophanol-derived oxazoloisoindolinones, anticancer chemotherapy

Received: June 17, $2015 \quad$ Accepted: November 28, $2015 \quad$ Published: December 28, 2015

\section{ABSTRACT}

Restoration of the p53 pathway, namely by reactivation of mutant (mut) p53, represents a valuable anticancer strategy. Herein, we report the identification of the enantiopure tryptophanol-derived oxazoloisoindolinone SLMP53-1 as a novel reactivator of wild-type $(\mathrm{wt})$ and mut p53, using a yeast-based screening strategy. SLMP53-1 has a p53-dependent anti-proliferative activity in human wt and mut p53R280K-expressing tumor cells. Additionally, SLMP53-1 enhances p53 transcriptional activity and restores wt-like DNA binding ability to mut p53R280K. In wt/ mut p53-expressing tumor cells, SLMP53-1 triggers p53 transcriptiondependent and mitochondrial apoptotic pathways involving BAX, and wt/ mut p53 mitochondrial translocation. SLMP53-1 inhibits the migration of wt/ mut p53-expressing tumor cells, and it shows promising p53-dependent synergistic effects with conventional chemotherapeutics. In xenograft mice models, SLMP53-1 inhibits the growth of wt/ mut p53-expressing tumors, but not of p53-null tumors, without apparent toxicity. Collectively, besides the potential use of SLMP53-1 as anticancer drug, the tryptophanol-derived oxazoloisoindolinone scaffold represents a promissing starting point for the development of effective p53-reactivating drugs.

\section{INTRODUCTION}

The p53 transcription factor finely regulates the expression of genes with central roles in cellular processes including DNA repair, cell cycle, and apoptosis [1, 2]. Compelling evidence has demonstrated that inactivation of the p53 pathway is required for tumor development and maintenance. In fact, in all human cancers bearing $\mathrm{p} 53$, this protein is inactivated by binding to endogenous inhibitors, such as murine double minute (MDM)2, or by mutation of the TP53 gene $[1,2]$. Therefore, p53 reactivation represents a highly effective strategy in cancer treatment [1].

The majority of p53 mutations are missense, preferentially localized in the DNA binding domain. They can be classified as structural (e.g., R175H, Y220C) or DNA contact (e.g., R273H, R280K) based on whether or not they lead to a profound protein conformational change, respectively. However, both types of mutations prevent the p53 binding to DNA, leading to the loss of wild-type (wt) p53 transcriptional activity [1-4]. Additionally, TP53 mutations may lead to the acquisition 
of gain-of-function (GOF) activities, responsible for more aggressive tumor phenotypes with increased invasive and metastatic potential, high chemoresistance, and poor prognosis [3-5]. Moreover, high levels of mutant (mut) p53 are often found in tumors due to a reduced MDM2 expression, and consequent impairment of $\mathrm{p} 53$ degradation [3]. Collectively, these observations support that mut p53 is a promising therapeutic target against a wide range of aggressive tumors [3-5].

To date, few small-molecule reactivators of mut $\mathrm{p} 53$ have been identified. Actually, due to its structural nature, the restoration of wt-like function to mut p53 has been challenging. Moreover, for most of the reported mut p53 reactivators, unfavorable pharmacokinetics and toxicity profiles have been described [6]. In fact, so far, only the PRIMA-1 derivative, APR-246, has reached clinical trials [1-3]. Therefore, more pharmacological alternatives for mut $\mathrm{p} 53$ reactivation are still required.

In this work, the enantiopure tryptophanol-derived oxazoloisoindolinone SLMP53-1 (Figure 1A) was identified as a new reactivator of wt and mut p53R280K. This compound revealed in vitro and in vivo p53-dependent antitumor activity, both alone and combined with conventional chemotherapeutics, against tumors bearing wt/mut p53.

\section{RESULTS}

\section{Identification of SLMP53-1 as activator of wt p53 and reactivator of mut $\mathrm{p} 53 \mathrm{R} 280 \mathrm{~K}$ from a yeast screening of a library of tryptophanol-derived oxazoloisoindolinones}

A yeast-based screening assay, consisting of Saccharomyces cerevisiae cells expressing human $\mathrm{wt}$ p53 or mut p53 (R280K or Y220C; two of the most prevalent forms of human mut p53 [7]), was developed to search for mut $\mathrm{p} 53$ reactivators (Figure 1B). This assay was established based on the yeast growth inhibitory effect induced by wt p53, but not by mut p53 [8]. Based on this phenotypic readout, mut p53 reactivators would reestablish the wt p53-dependent growth inhibition. Since, to date, mut p53R280K reactivators remain unknown, the mut p53Y220C reactivator PhiKan083 [9] was used to attest the efficacy of the yeast assay (Figure 1B). In yeast, $50 \mu \mathrm{M}$ PhiKan083 restored the wt p53-induced growth inhibition to mut p53Y220C (in about 63\%; Figure 1B).

This yeast assay was thereafter used to evaluate the effect of synthesized enantiopure tryptophanol-derived oxazoloisoindolinones on wt and mut p53 activity. These compounds were synthesized following our interest in enantiopure biologically active amino alcohol-derived compounds [10-12], and on our previous discovery of phenylalaninol-derived oxazoloisoindolinones with in vitro p53-dependent antitumor activity [10]. With this new library, we intended to study the effect on p53 activity of the replacement of the phenyl moiety (present in our first set of compounds [10]) by an indole moiety. Among the compounds tested, SLMP53-1 behaved as an activator of wt p53 and reactivator of mut p53R280K (Figure 1B and $1 \mathrm{C}$ ). Actually, at $10 \mu \mathrm{M}$ (lowest concentration, from a range of $1-50 \mu \mathrm{M}$, that caused a maximal effect; data not shown), SLMP53-1 increased the wt p53-induced yeast growth inhibition and restored the wt-like growth inhibitory effect to mut p53R280K (in about 79\%; Figure 1B), without interfering with the growth of control yeast (data not shown). Consistently, $10 \mu$ M SLMP53-1 increased the $\mathrm{S}$ - and G2/M-phases cell cycle arrest in wt p53-expressing yeast, and reestablished the wt-like cell cycle arrest in mut p53R280K-expressing yeast (Figure 1C). Interestingly, 1-50 $\mu$ M SLMP53-1 did not interfere with the growth of mut p53Y220C-expressing yeast (Figure 1B).

A previous work [13] corroborated the conservation in yeast of the p53 transcriptional activity, and established its correlation with $\mathrm{p} 53$-induced growth inhibition using pifithrin- $\alpha$ (PFT- $\alpha$; known selective inhibitor of p53 transcriptional activity [14]). Accordingly with previous results [13], in the present work, the treatment of yeast cells expressing wt p53 with $5 \mu \mathrm{M}$ PFT- $\alpha$ reduced the wt p53-induced growth inhibition by $68.0 \pm 1.1 \%(n=4)$. Additionally, in the presence of $5 \mu \mathrm{M}$ PFT- $\alpha, 10 \mu \mathrm{M}$ SLMP53-1 increased the wt $\mathrm{p} 53$-inhibitory effect by only $5.8 \pm 0.8 \%$ ( $n=4$; relative to PFT- $\alpha$ only). A similar result was obtained with yeast cells expressing mut p53R280K. In fact, in these cells, $10 \mu \mathrm{M}$ SLMP53-1 induced a mut p53 inhibitory effect of $2.5 \pm 1.1 \%(n=4$; relative to PFT- $\alpha$ only). These results established a correlation between the activation of p53 transcriptional activity by SLMP53-1 and its cytotoxicity in yeast, since in the presence of a p53 transcriptional inhibitor, the activity of SLMP53-1 was abolished.

\section{Growth inhibitory effect of SLMP53-1 on wt p53- and mut p53R280K-expressing tumor cells is mediated by a p53-dependent cell cycle arrest and/or apoptosis}

The growth inhibitory potential of SLMP53-1, and the contribution of the p53 pathway to its activity, were ascertained in $\mathrm{p} 53^{+/+}$and $\mathrm{p} 53^{-/-} \mathrm{HCT} 116$ tumor cells. A significant difference between the $\mathrm{GI}_{50}$ (concentration for $50 \%$ of maximal growth inhibition) values obtained in $\mathrm{p}^{+/+}(\sim 16 \mu \mathrm{M})$ and $\mathrm{p} 53^{-/-}(\sim 34 \mu \mathrm{M})$ HCT116 cells indicated an involvement of p53 in the growth inhibitory effect of SLMP53-1 (Figure 2A). Conversely, no significant differences were observed between the $\mathrm{GI}_{50}$ values of PRIMA-1 in p53 $3^{+/+}$and $\mathrm{p} 53^{-/+}$HCT116 cells (Figure 2A). In our experimental conditions, the $\mathrm{GI}_{50}$ value of PhiKan083 in HCT116 cells was higher than $150 \mu \mathrm{M}$.

The SLMP53-1 growth inhibitory effect was associated with G0/G1-phase cell cycle arrest (Figure 2B), and apoptosis (Figure 2C) in $\mathrm{p} 53^{+/+}$, but 
not in $\mathrm{p} 53^{-/-}$, HCT116 cells. The enhancement of PARP cleavage by $16 \mu \mathrm{M}$ SLMP53-1 in $\mathrm{p}^{2} 3^{+/}$, but not in $\mathrm{p} 53^{-/-}$, HCT116 cells further corroborated the activation of a p53dependent apoptotic pathway (Figure 2D).

Consistent with the yeast results, SLMP53-1 also inhibited the growth of mut p53R280K-expressing MDA-MB-231 cells with a $\mathrm{GI}_{50}$ value similar to that obtained in HCT116p53 $53^{+/+}$cells $(\sim 16 \mu \mathrm{M}$; Figure $2 \mathrm{E})$.
Moreover, it presented a much lower growth inhibitory activity against mut p53Y220C-expressing $\mathrm{HuH}-7$ cells (Figure 2E). When compared to PRIMA-1, SLMP53-1 presented a higher potency in MDA-MB-231 cells, but was less potent against mut p53Y220C-expressing HuH-7 cells (Figure 2E). In our experimental conditions, the $\mathrm{GI}_{50}$ values of PhiKan083 in MDA-MB-231 and HuH-7 cells were higher than $150 \mu \mathrm{M}$.

A<smiles>N[C@@H](CO)Cc1c[nH]c2ccccc12</smiles><smiles>COc1ccccc1C(=O)O</smiles>

B
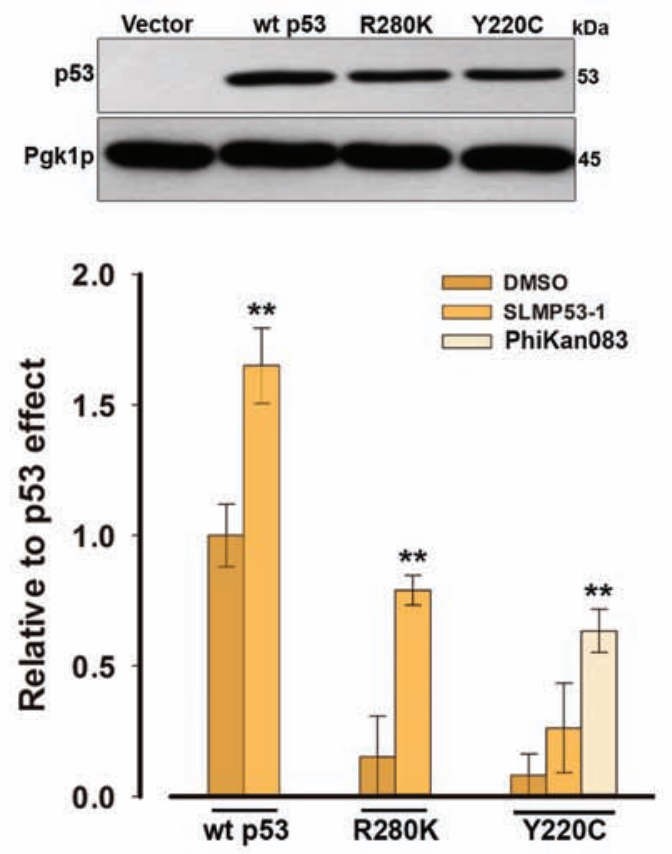

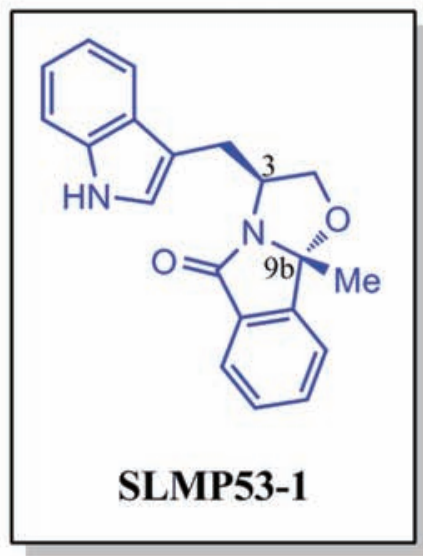<smiles>C[C@]12OC[C@@H](Cc3c[nH]c4ccccc34)N1C(=O)c1ccccc12</smiles>

\section{SLMP53-1 enantiomer}

\section{C}

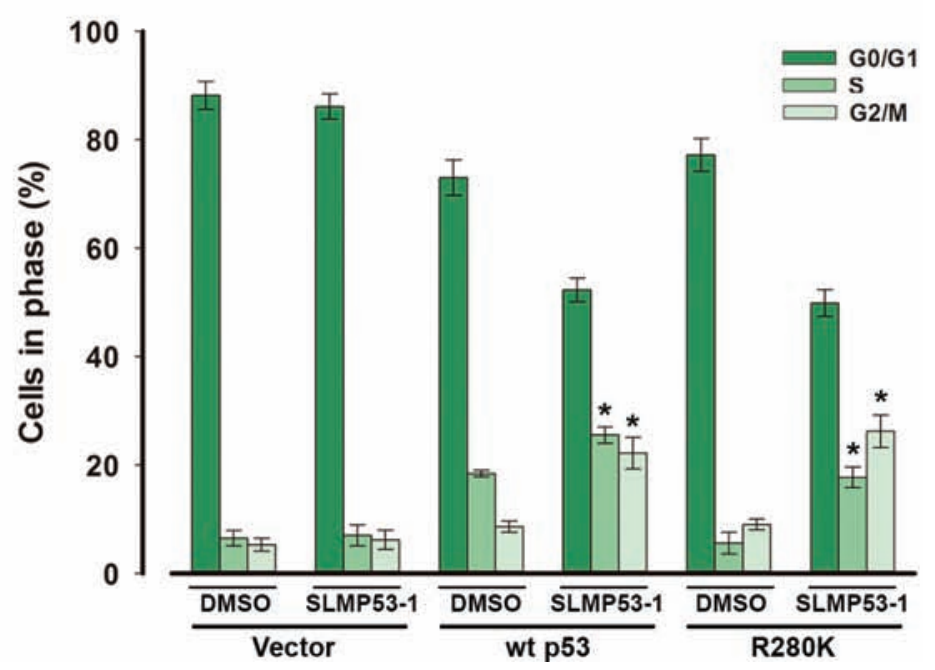

Figure 1: SLMP53-1 activates wt p53 and restores the wt-like activity to mut p53R280K in yeast. (A) Synthesis of SLMP53-1 and chemical structure of its enantiomer. (B) Immunoblots of human wt p53, mut p53R280K and mut p53Y220C expressed in yeast after $30 \mathrm{~h}$ incubation in selective induction medium (representative of three independent experiments). Graphical representation: increase of wt and mut p53R280K-induced growth inhibition by $10 \mu \mathrm{M}$ SLMP53-1 and of mut p53Y220C-induced growth inhibition by $50 \mu \mathrm{M}$ PhiKan083, after $30 \mathrm{~h}$; results were plotted setting as 1 the growth inhibitory effect of wt p53-expressing cells treated with DMSO only; data are mean \pm SEM $(n=5)$. (C) Increase of wt and mut p53R280K-induced yeast cell cycle arrest by $10 \mu \mathrm{M}$ SLMP53-1; data are mean $\pm \operatorname{SEM}(n=3)$. In B and C, values significantly different from DMSO only: ${ }^{*} p<0.05,{ }^{* *} p<0.01$. 
Interestingly, in MDA-MB-231 cells, despite not interfering with cell cycle progression (Figure 2F), $16 \mu \mathrm{M}$ SLMP53-1 stimulated cell death, as revealed by the increase of late apoptosis (Figure 2G) and PARP cleavage (Figure 2H).

\section{SLMP53-1 selectively activates p53 transcriptional activity and reestablishes mut p53R280K DNA binding ability}

The effect of SLMP53-1 on wt p53 and mut p53R280K activity was investigated by analysis of the expression levels of proteins encoded by $\mathrm{p} 53$ target genes in HCT116p53 $3^{+/+}$, HCT116p53 $3^{-/}$, and MDA-MB-231 cells.

In HCT116p53 $3^{++}$cells, $16 \mu \mathrm{M}$ SLMP53-1 increased the p53, MDM2, p21, PUMA and BAX expression levels (Figure 3A). Instead, the levels of these proteins were not significantly changed in HCT116p53 $3^{-/}$cells treated with $16 \mu \mathrm{M}$ SLMP53-1, supporting the p53-dependent activity of this molecule (Figure 3A). Additionally, $16 \mu \mathrm{M}$ SLMP53-1 increased the mRNA levels of CDKN1A (p21) and TNFRSF10B (KILLER) in HCT116p53 $3^{+/+}$cells (Figure 3B). The selective activation of $\mathrm{p} 53$ transcriptional activity by SLMP53-1 was further reinforced by a dual-luciferase gene reporter assay using $\mathrm{p} 53^{+/+}$and $\mathrm{p} 53^{-/-}$HCT116 cells transfected with $\mathrm{p} 21$ - or MDM2-luciferase reporter vectors. At $16 \mu \mathrm{M}$ and $32 \mu \mathrm{M}\left(2 \times \mathrm{GI}_{50}\right)$, SLMP53-1 increased the expression of the two p53 reporters in HCT116p53 $3^{++}$cells, while no effect was observed in HCT116p53 $3^{-/}$cells (Figure 3C).

In MDA-MB-231 cells, $16 \mu \mathrm{M}$ SLMP53-1 increased MDM2, PUMA and BAX protein levels, with no apparent increase of p53 protein levels (Figure 3D). The lack of mut $\mathrm{p} 53$ protein stabilization was already reported for other mut $\mathrm{p} 53$ reactivators, and has been attributed to a reestablishment of the MDM2-mediated p53 degradation [15]. Moreover, consistent with the lack of effect on cell cycle progression, $16 \mu \mathrm{M}$ SLMP53-1 did not affect p2 1 protein levels (Figure 3D).

The restoration of mut p53R280K DNA binding ability by SLMP53-1 was assessed by TransAM DNA binding assay, using MDA-MB-231 cells. The results revealed a dose-dependent enhancement of the amount of p53 bound to DNA by SLMP53-1 relative to cells treated with DMSO only (Figure 3E).

To further demonstrate that the SLMP53-1 effects were dependent on mut p53R280K in MDA-MB-231 cells, mut p53R280K was knocked-down by p53siRNA. In cells transfected with non-specific siRNA (siRNA-NS; control), $16 \mu$ M SLMP53-1 increased the protein levels of PUMA, BAX and cleaved PARP, as observed in non-transfected cells (Figure 3F). As expected, these SLMP53-1 effects were efficiently abolished by mut p53 silencing (Figure 3F).

\section{SLMP53-1 triggers a p53-dependent mitochondrial apoptotic pathway in wt p53- and mut p53R280K-expressing tumor cells}

In HCT116p53 $3^{+/+}$and MDA-MB-231 cells, $16 \mu \mathrm{M}$ SLMP53-1 led to mitochondrial membrane potential $\left(\Delta \psi_{\mathrm{m}}\right)$ dissipation and reactive oxygen species (ROS) generation (Figure 4A). Consistent with p53-dependence, these effects were not observed in $16 \mu \mathrm{M}$ SLMP53-1treated HCT116p53 $3^{-/}$cells (Figure 4A). Additionally, in HCT116p53 $3^{+/+}$(Figure 4B) and MDA-MB-231 (Figure 4C) cells, $16 \mu \mathrm{M}$ SLMP53-1 triggered BAX, wt p53 (Figure 4B) and mut p53R280K (Figure 4C) mitochondrial translocation, and led to cytochrome $c$ (cyt $c$ ) release to cytosol (Figure 4B and 4C). Altogether, these results showed that SLMP53-1 induced a p53-dependent mitochondrial apoptotic pathway in both wt p53- and mut p53R280K-expressing tumor cells.

\section{SLMP53-1 inhibits the migration of wt p53- and mut p53R280K-expressing tumor cells}

The results obtained in the wound healing assay showed that the $\mathrm{GI}_{10}$ concentration $(4 \mu \mathrm{M})$ of SLMP53-1 reduced the migration of HCT116p53 $3^{++}$and MDA-MB-231 tumor cells (Figure 5A and 5B). These results were corroborated by the chemotaxis cell migration assay, in which the $\mathrm{GI}_{25}$ concentration $(7 \mu \mathrm{M})$ of SLMP53-1 led to over $50 \%$ reduction of HCT116p53 $3^{+/+}$cell migration compared to DMSO only (Figure 5C). A similar result was obtained with the constitutively more motile MDA-MB-231 cells treated with $16 \mu \mathrm{M}$ SLMP53-1 (Figure 5C). These data showed that SLMP53-1 inhibited the in vitro migration of both wt p53- and mut p53R280K-expressing tumor cells.

\section{SLMP53-1 sensitizes wt p53- and mut p53R280K-expressing tumor cells to conventional chemotherapeutics in a p53-dependent manner}

We investigated whether SLMP53-1 increased the sensitivity of HCT116p53 $53^{+/+}$and MDA-MB-231 tumor cells to conventional chemotherapeutics. For that, a low concentration of SLMP53-1, with no significant growth inhibitory effects $\left(\mathrm{GI}_{10}\right.$ of $\left.4 \mu \mathrm{M}\right)$, was combined with increasing concentrations of doxorubicin and etoposide. In HCT116p53 $3^{+/+}$cells, SLMP53-1 showed synergistic effects with all tested concentrations of chemotherapeutics $(Q>1.15)$, although the most pronounced effects were obtained with doxorubicin (Figure 6A). Conversely, no synergistic effects were observed between SLMP53-1 and the chemotherapeutics in HCT116p53 $3^{--}$cells (Figure 6B). As in HCT116p53 $3^{+/+}$cells, synergistic effects between SLMP53-1 and all tested concentrations of doxorubicin and etoposide were also observed in MDA-MB-231 cells $(Q>1.15)$ (Figure 6C). Interestingly, pronounced synergistic effects between $4 \mu \mathrm{M}$ SLMP53-1 and the 
A

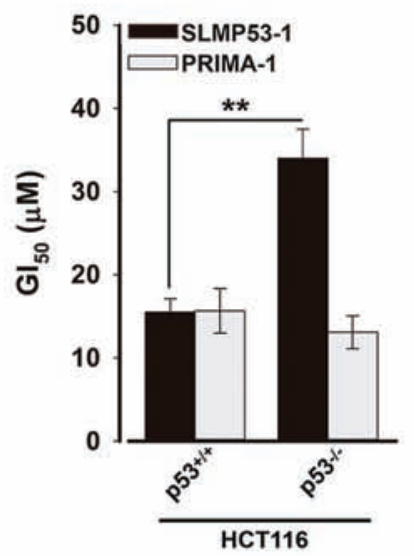

D

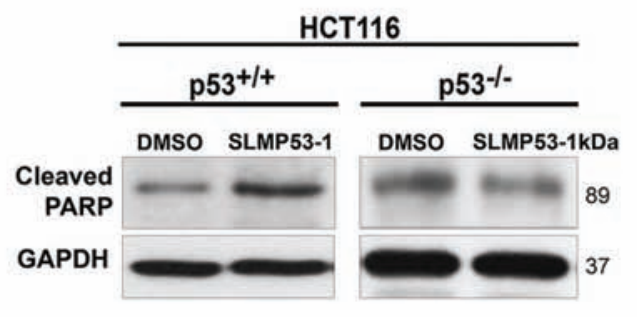

E
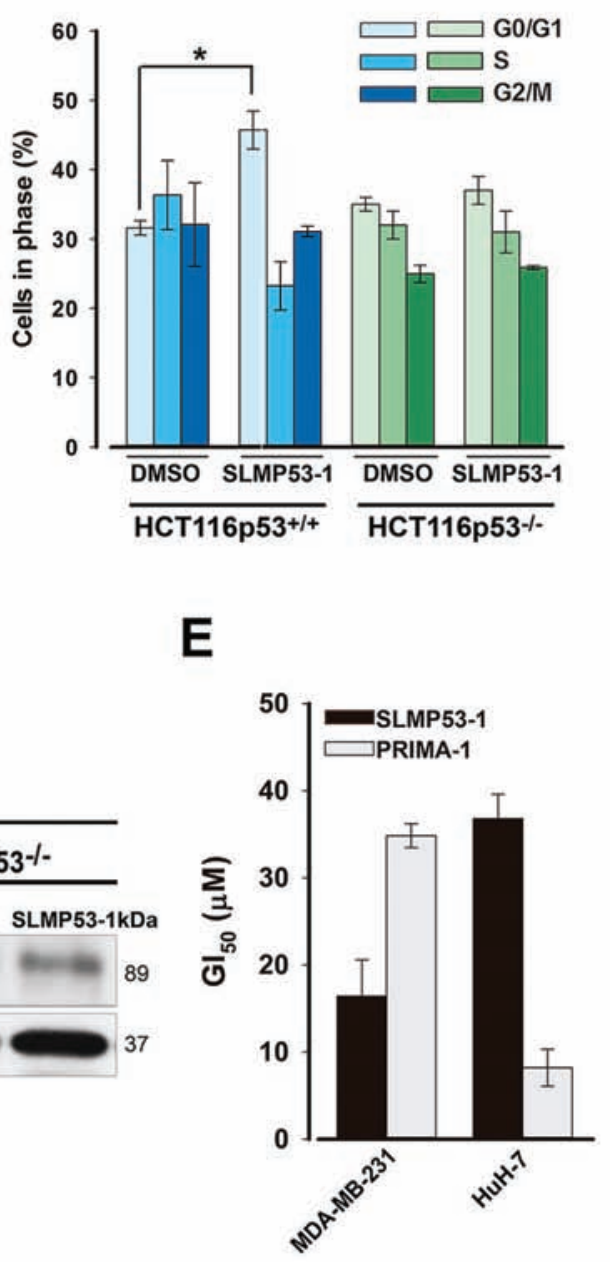

C
F

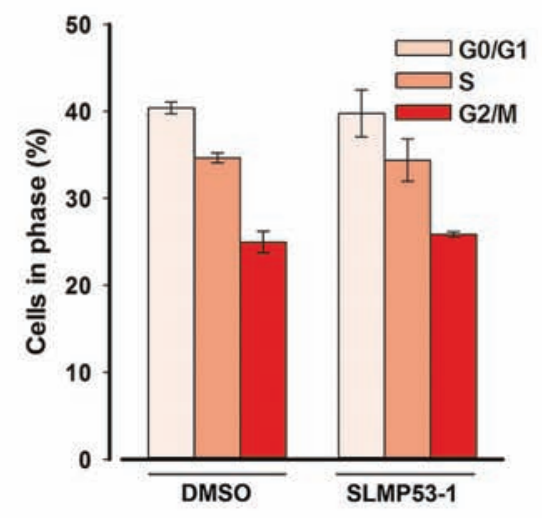

H

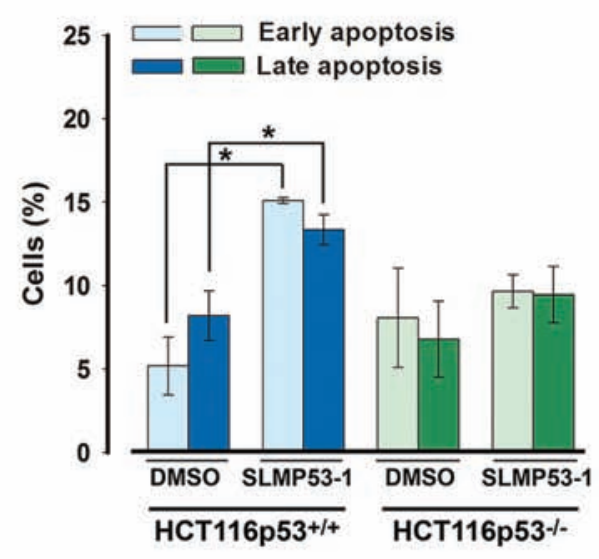

G

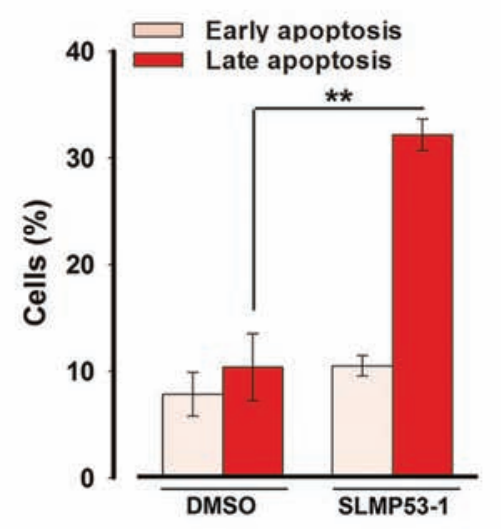

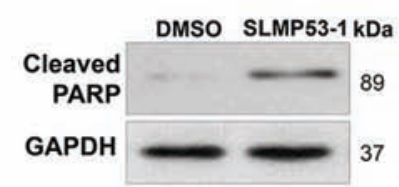

Figure 2: SLMP53-1 growth inhibitory effect in human wt p53- and mut p53R280K-expressing tumor cells is mediated by p53-dependent cell cycle arrest and/or apoptosis. (A) GI value of SLMP53-1 in HCT116 cells, after $48 \mathrm{~h}$ treatment; values significantly different: ${ }^{*} p<0.01$. (B) Cell cycle, (C) Apoptosis and (D) PARP cleavage after $24 \mathrm{~h}$ with $16 \mu$ M SLMP53-1 in HCT116 cells. (E) GI $_{50}$ value for SLMP53-1 in MDA-MB-231 (mut p53R280K) and HuH-7 (mut p53Y220C) cells, after 48 h treatment. (F) Cell cycle, (G) Apoptosis and (H) PARP cleavage after $24 \mathrm{~h}$ with $16 \mu \mathrm{M}$ SLMP53-1 in MDA-MB-231 cells. In A-C and E-G, data are mean \pm SEM $(n=3-4)$. In A, B, C and G, values significantly different from DMSO only: ${ }^{*} p<0.05,{ }^{* *} p<0.01$. In F, values are not significantly different from DMSO only: $p>0.05$. In $\mathrm{D}$ and $\mathrm{H}$ immunoblots are representative of three independent experiments. 
A
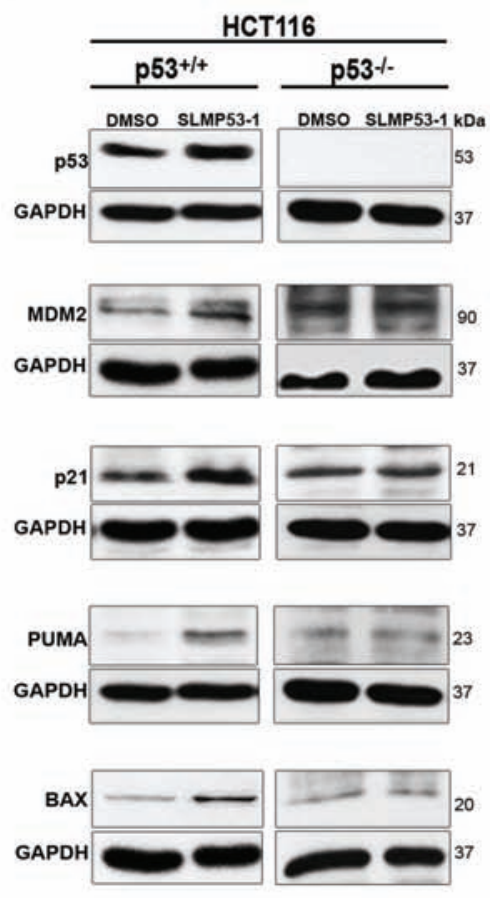

B

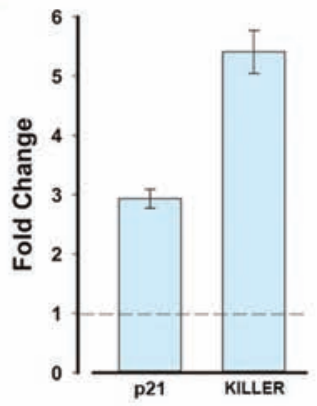

C

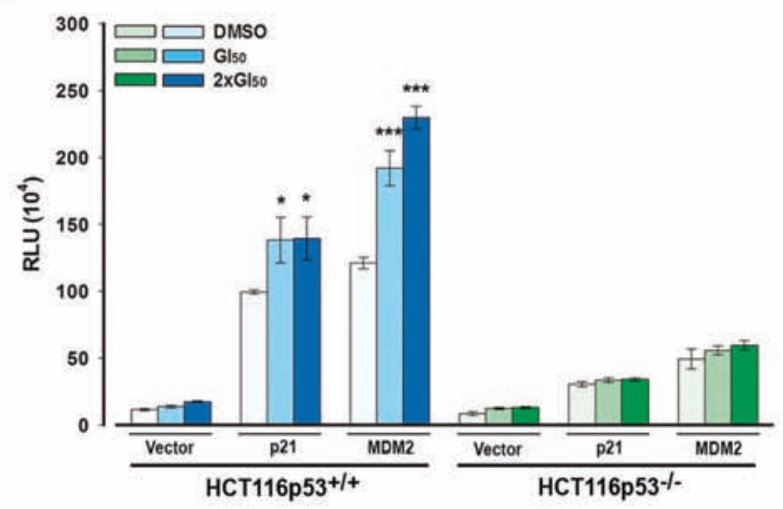

D

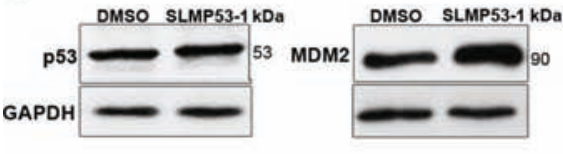

E

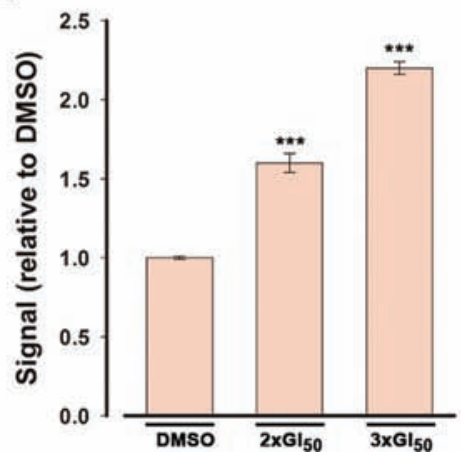

F

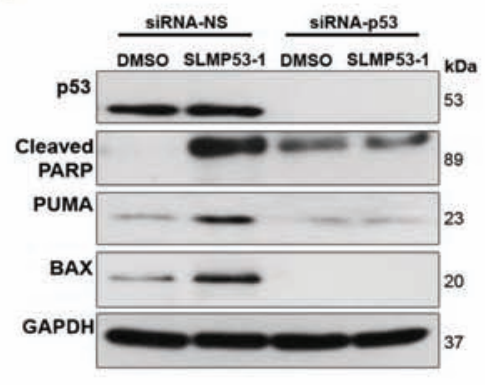

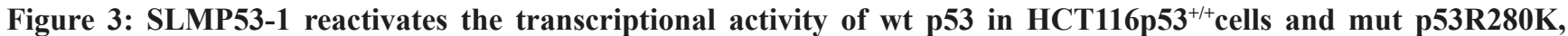
through reestablishment of its DNA binding ability, in MDA-MB-231 cells. (A) Protein levels of p53 target genes, and (B) gene expression of CDKN1A (p21) and TNFRSF10B (KILLER), after $24 \mathrm{~h}$ with $16 \mu \mathrm{M}$ SLMP53-1 in HCT116 cells. In B, fold expression changes are relative to DMSO and correspond to mean \pm SEM $(n=3)$. (C) p53 transcriptional activity after $16 \mathrm{~h}$ with $16 \mu \mathrm{M}$ and $32 \mu \mathrm{M}\left(2 \times \mathrm{GI}_{50}\right)$ SLMP53-1 in HCT116 cells assessed by dual-luciferase gene reporter assay. Data are plotted as mean relative light units (RLU) \pm SEM $(n=3)$; values significantly different from DMSO only: $* p<0.05, * * p<0.001$. (D) Protein levels of p53 target genes after $24 \mathrm{~h}$ with $16 \mu \mathrm{M}$ SLMP53-1 in MDA-MB-231 cells. (E) DNA binding affinity of mut p53R280K after $24 \mathrm{~h}$ with $32 \mu \mathrm{M}$ and $48 \mu \mathrm{M}\left(3 \times \mathrm{GI}_{50}\right)$ SLMP53-1 in MDA-MB-231 cells; the signal obtained with DMSO only was set as 1; data are mean $\pm \operatorname{SEM}(n=3)$; values significantly different from DMSO only: ${ }^{* * *} p<0.001$. (F) PARP cleavage and protein levels of PUMA and BAX after $24 \mathrm{~h}$ with $16 \mu \mathrm{M}$ SLMP53-1 in mut p53R280K-silenced MDA-MB-231 cells. In A, D and F, immunoblots are representative of three independent experiments. 
A
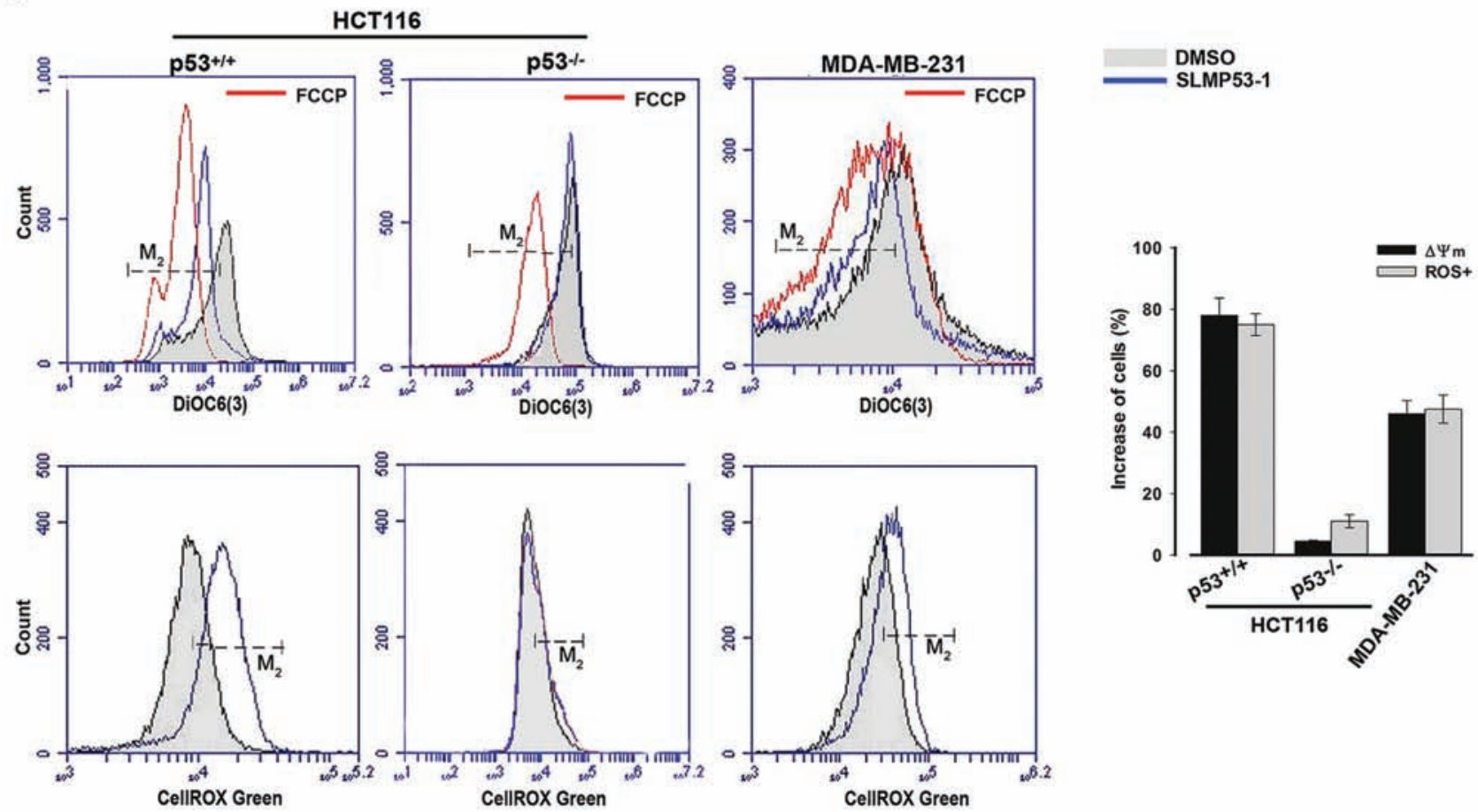

B
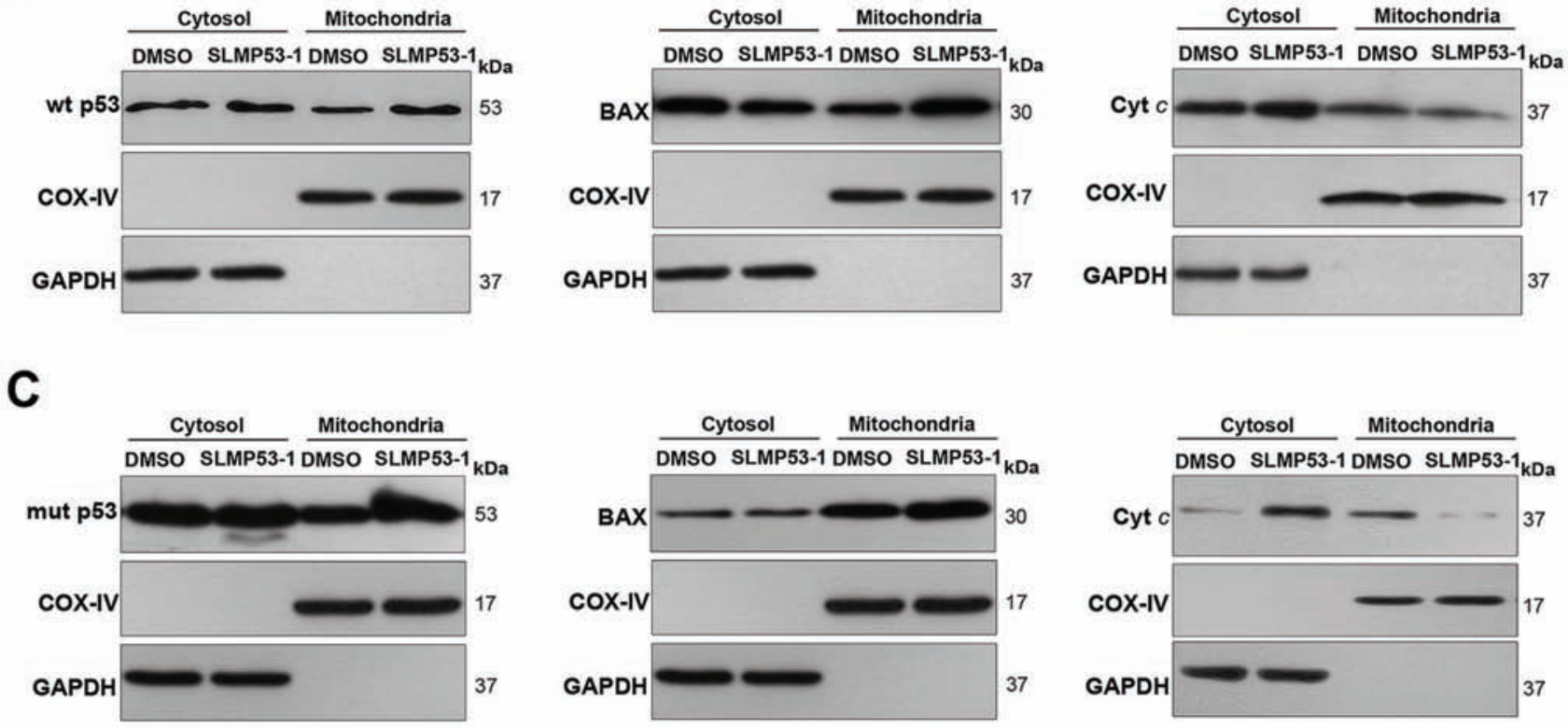

Figure 4: SLMP53-1 triggers a p53-mediated mitochondrial apoptotic pathway in HCT116p53 ${ }^{+/+}$and MDA-MB-231 cells. (A) Cells were treated with $16 \mu \mathrm{M}$ SLMP53-1 for $8 \mathrm{~h}$ (HCT116 cells) or $16 \mathrm{~h}$ (MDA-MB-231 cells) in $\Delta \psi_{\mathrm{m}}$ analysis, and for $24 \mathrm{~h}$ in ROS analysis. Carbonyl cyanide-p-trifluoromethoxyphenylhydrazone (FCCP) was used as positive control in $\Delta \psi_{\mathrm{m}}$; histograms are representative of three independent experiments; $\mathrm{M}_{2}$ cursor indicates the subpopulation analyzed. Graphical representation: increase in the percentage of cells with $\Delta \psi_{\mathrm{m}}$ dissipation and ROS generation; values are mean $\pm \operatorname{SEM}(n=3)$. (B) and (C) Immunoblots of wt $/ \mathrm{mut}$ p53, BAX and cyt $c$, in cytosolic and mitochondrial fractions of (B) HCT116p53 $3^{++}$and (C) MDA-MB-231 cells after $16 \mathrm{~h}$ with $16 \mu \mathrm{M}$ SLMP53-1. In $\mathrm{B}$ and $\mathrm{C}$, immunoblots are representative of three independent experiments. 
A

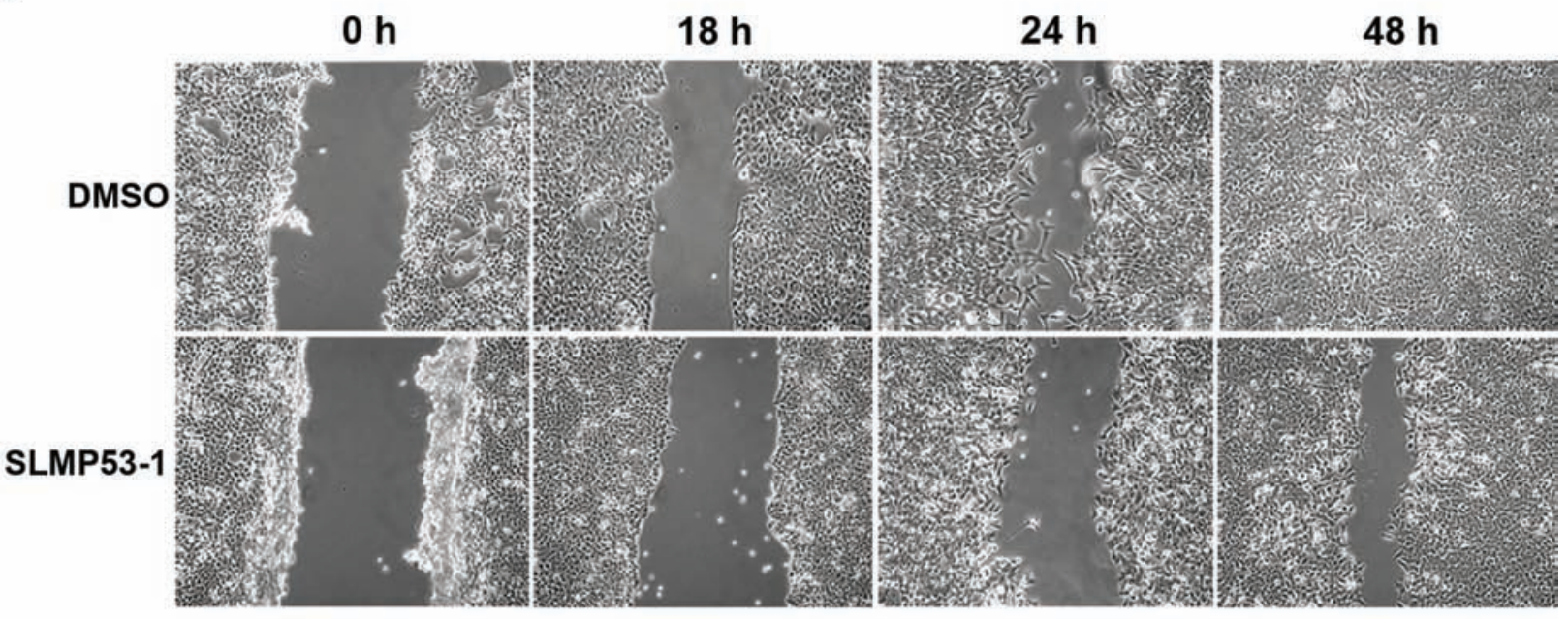

B
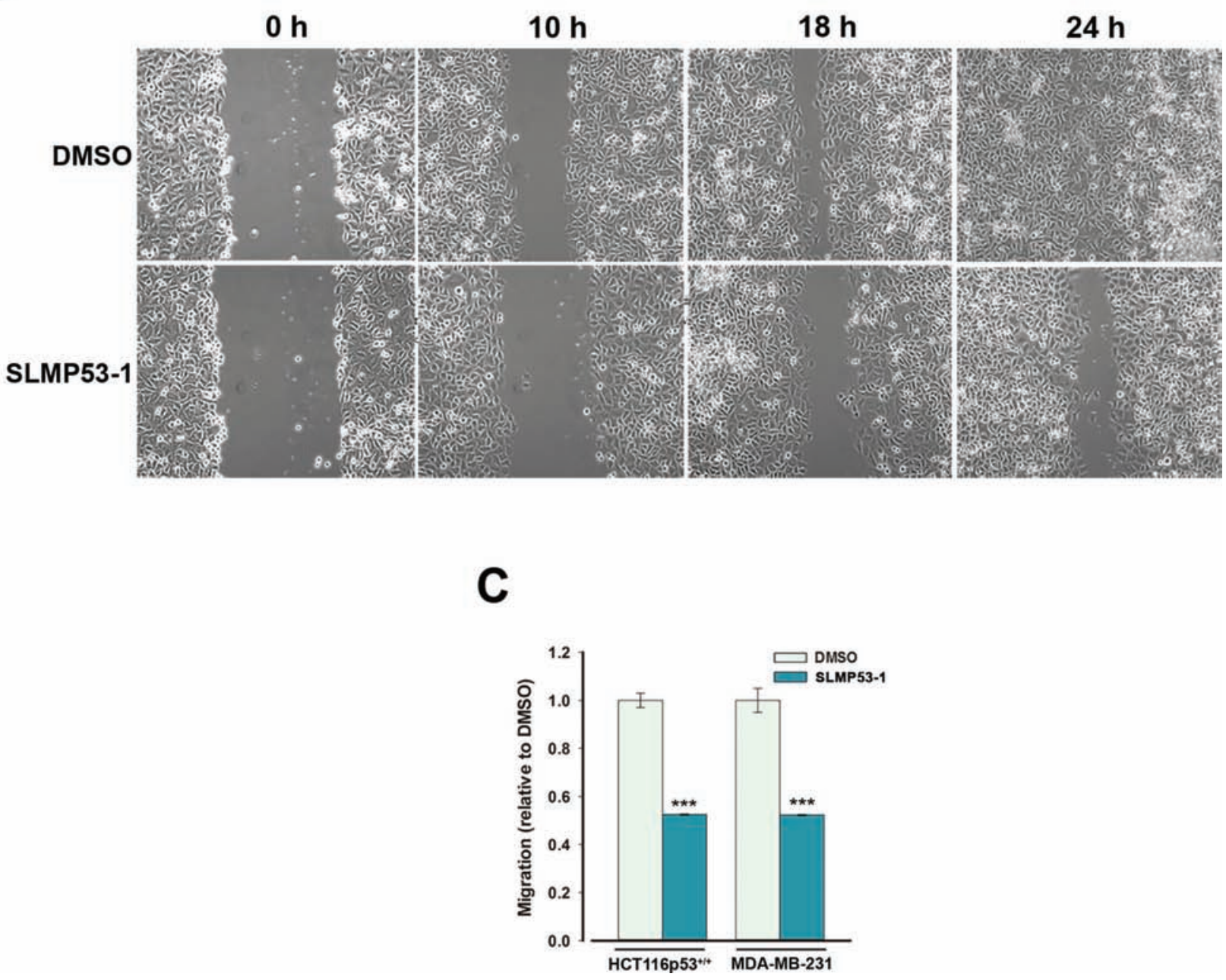

Figure 5: SLMP53-1 prevents the migration of HCT116p53 ${ }^{+/+}$and MDA-MB-231 cells. (A) HCT116p53 ${ }^{+/+}$and (B) MDA-MB-231 confluent cells treated with $4 \mu \mathrm{M}$ SLMP53-1 (or DMSO only) were observed at different time-points in the wound healing assay. (C) Effects of SLMP53-1 on the migration of HCT116p53 ${ }^{+/+}(7 \mu \mathrm{M}$ for $24 \mathrm{~h})$ and MDA-MB-231 (16 $\mu \mathrm{M}$ for $\left.8 \mathrm{~h}\right)$ cells analyzed by the chemotaxis assay; the migratory cells were quantified by fluorescence signal, setting as 1 cells treated with DMSO only; data are mean $\pm \operatorname{SEM}(n=3)$; values significantly different from DMSO only: $* * * p<0.001$. 
lowest tested concentrations of doxorubicin $(0.19 \mu \mathrm{M})$ and etoposide $(0.38 \mu \mathrm{M})$ were also evident regarding total apoptosis in MDA-MB-231 cells $(Q>1.15$; Figure 6D). Altogether, these results show p53-dependent synergistic effects of SLMP53-1 with conventional chemotherapeutics.

\section{SLMP53-1 has no in vitro toxicity in non-tumorigenic cells}

The potential genotoxicity of SLMP53-1 was investigated using the cytokinesis-block micronucleus assay. At $16 \mu \mathrm{M}$, SLMP53-1 did not increase the number of micronuclei in lymphocytes when compared to DMSO only (Figure 7A). Additionally, $16 \mu \mathrm{M}$ SLMP53-1 induced only $5.6 \pm 3.2 \%(n=5)$ growth inhibition in non-tumorigenic MCF10A cells, showing that this concentration is not toxic to normal cells. Furthermore, unlike in tumor cells, in MCF10A cells, the growth inhibition induced by SLMP53-1 at $\mathrm{GI}_{50}$ concentration $(42.4 \pm 2.9 \mu \mathrm{M}, n=5)$ was associated with G0/G1-cell cycle arrest (Figure 7B), but not with apoptosis (Figure 7C).

\section{SLMP53-1 has potent in vivo antitumor activity with no evident toxicity}

To evaluate the in vivo antitumor potential of SLMP53-1, mice xenograft models carrying HCT116p53 $3^{+/+}$, HCT116p53 $3^{-/-}$, or MDA-MB-231 tumor cells were used. The results revealed that four intraperitoneal administrations (twice a week) of $50 \mathrm{mg} / \mathrm{kg}$ SLMP53-1 were highly effective, blocking the growth of HCT116p53 $3^{+/+}$tumors (Figure 7D) compared to control (vehicle). Most importantly, SLMP53-1 had no effect on HCT116p53 $3^{-/-}$tumor xenografts, corroborating its p53-dependent antitumor activity (Figure 7D). Potent antitumor activity was also established for MDA-MB-231 tumors, confirming the in vivo efficacy of SLMP53-1 against mut p53R280K-expressing tumors (Figure 7D). No significant loss of body weight or morbidity signs were observed in treated mice compared to control, throughout the experimental period (Figure 7E).

Considering the common chemotherapeutic side effects, some primary toxicity signs potentially triggered by SLMP53-1 were investigated in Wistar rats. For that, the organs relative weight (trophism), as well as biochemical and hematological data were analyzed for three rat groups (saline, vehicle and SLMP53-1) (Supplementary Table 1). No differences between the three groups on relative weight of liver, kidneys, heart and lungs were observed. Concerning biochemical data, only a slight decrease of urea in the vehicle group compared to saline group, and a slight decrease of uric acid and albumin in the SLMP53-1 group compared to vehicle group were observed. Hence, no evident liver or kidney toxicity was detected in SLMP53-1-treated group. Finally, concerning hematological data, just a small increase on the reticulocytes number was observed in the vehicle group compared to saline group, with no alterations between the SLMP53-1 and vehicle groups. Altogether, no apparent toxic side effects were observed for SLMP53-1 on the tissues most commonly affected by conventional chemotherapeutics.

In order to assess the proliferation and apoptotic status of tumors, immunohistochemistry and TUNEL staining were performed for tumor tissues (Figure 8). Both HCT116p53 $3^{+/+}$and MDA-MB-231 tumors, treated with SLMP53-1, showed low Ki-67-positive staining (indicative of a low proliferative status), when compared to tumors treated with vehicle (Figure 8). Additionally, a marked increase of BAX expression levels in SLMP53-1treated tumor tissues, compared to vehicle, was observed (Figure 8). In addition, a pronounced increase of nuclei DNA fragmentation upon SLMP53-1 treatment was observed (Figure 8). On the other hand, a uniform pattern, characterized by high levels of Ki-67 and low levels of BAX expression and DNA fragmentation, between HCT116p53 ${ }^{-/}$tumors treated with SLMP53-1 and vehicle was obtained (Figure 8).

\section{DISCUSSION}

From the analysis of a chemical library of novel enantiopure tryptophanol-derived oxazoloisoindolinones [16], the small-molecule SLMP53-1 was identified as a new reactivator of wt $\mathrm{p} 53$ and mut p53R280K. Considering the relevance of the absolute stereochemical configuration of biologically active compounds, the enantiomer of SLMP53-1 was also synthesized (Figure 1A). Interestingly, this enantiomer was inactive in yeast and exhibited a much lower growth inhibitory effect against wt/mut p53 bearing tumor cells compared to SLMP53-1 (data not shown). These results highlight the relevance of the stereochemistry at positions $\mathrm{C}-3$ and $\mathrm{C}-9 \mathrm{~b}$ for the activity of SLMP53-1.

The activation of wt p53 and mut p53R280K (a DNA contact mutant without major structural alterations), associated with the absence of effect on structural mut p53Y220C, lead us to hypothesize some preference of SLMP53-1 for the wt-like conformation of p53. Further studies are underway to analyze the activity of SLMP53-1 on other mut p53s.

Contrary to PRIMA-1, SLMP53-1 showed a p53-dependent tumor growth inhibitory activity. In fact, the induction of cell cycle arrest and apoptosis, and the enhancement of p53 transcriptional activity by SLMP53-1 in wt p53-expressing HCT116 tumor cells were completely abolished in p53-null HCT116 cells. In turn, SLMP53-1 showed a much higher cytotoxicity against mut p53R280K-expressing MDA-MB-231 cells than PRIMA-1 (with previously reported cytotoxicity against this tumor cell line [17]). In these tumor cells, SLMP53-1 
A
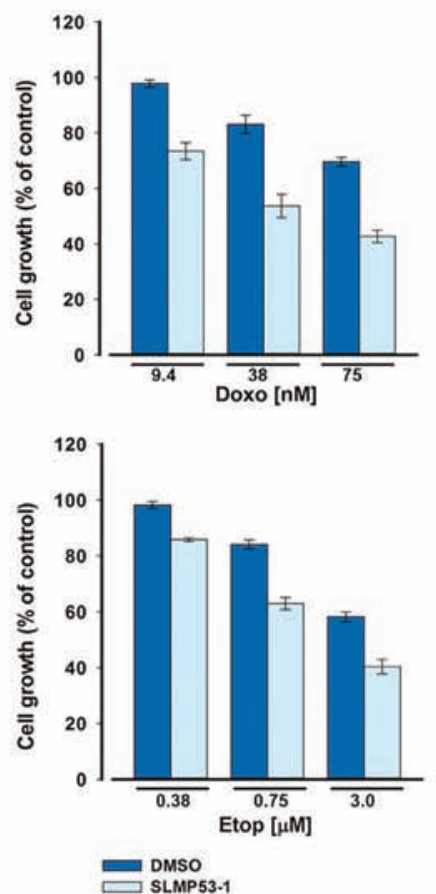

C

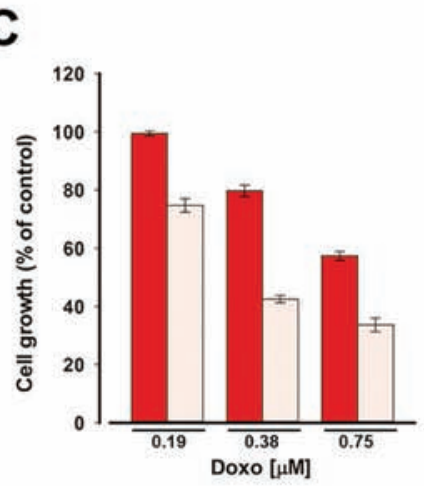

DMSO
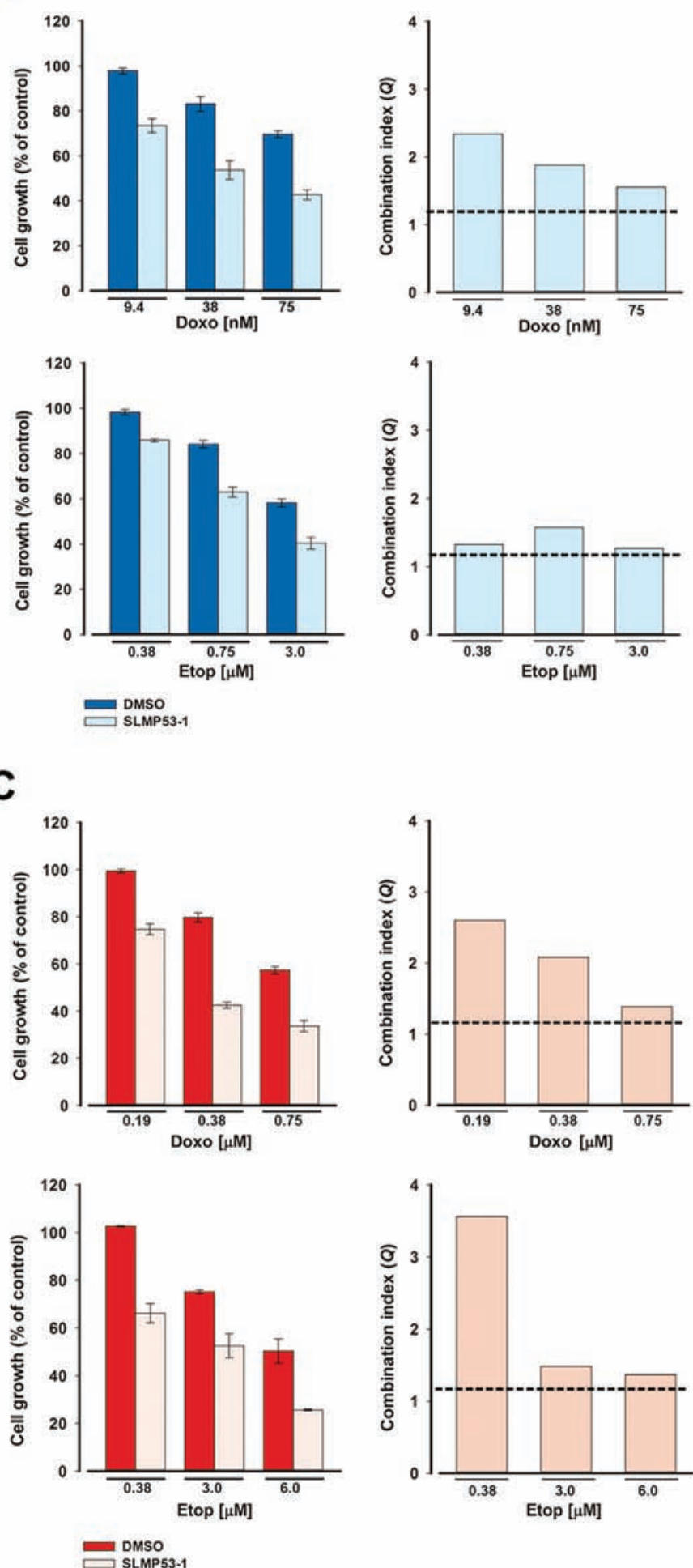

B
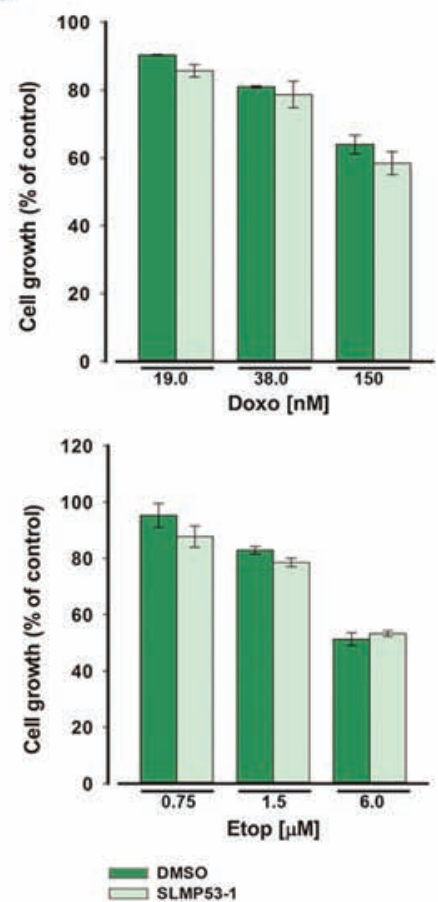

D

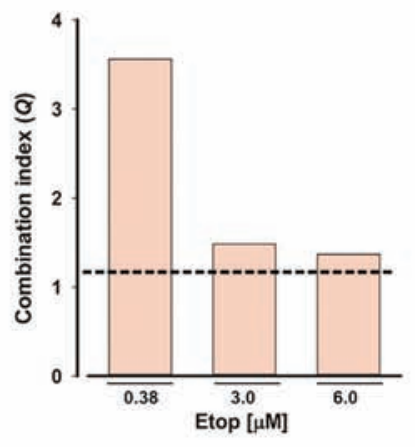

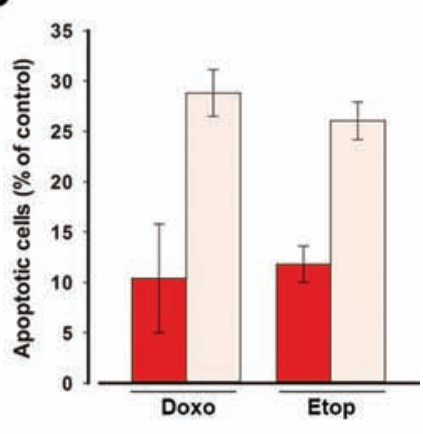

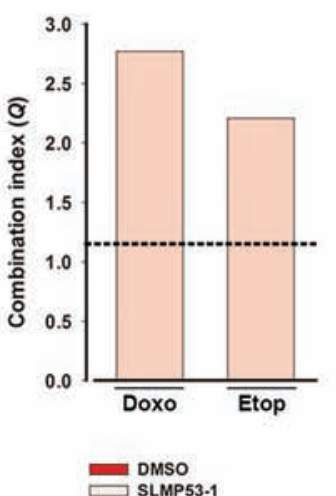

Figure 6: SLMP53-1 sensitizes HCT116p53 ${ }^{+/+}$and MDA-MB-231 cells to the effects of etoposide and doxorubicin. (A-C) Effects of combined treatment with $4 \mu \mathrm{M}$ SLMP53-1 (or DMSO only) and increasing concentrations of doxorubicin (Doxo) or etoposide (Etop) on tumor cell growth, after $48 \mathrm{~h}$; data are mean \pm SEM $(n=4)$; the percentage of cell growth achieved with SLMP53-1 only was (A) $90.3 \%$ in HCT116p53+/+ (B) $99.8 \%$ in HCT116p53 $53^{-/}$and (C) $90.5 \%$ in MDA-MB-231 cells. (D) Effects of combined treatment with $4 \mu \mathrm{M}$ SLMP53-1 (or DMSO only) and $0.19 \mu \mathrm{M}$ doxorubicin or $0.38 \mu \mathrm{M}$ etoposide on apoptosis after $48 \mathrm{~h}$ in MDA-MB-231 cells. The percentage of apoptotic cells obtained with SLMP53-1 only was $0.2 \%$; data are mean $\pm \operatorname{SEM}(n=3)$. In A, C and D, the $Q$ values are represented; dotted line represents $Q=1.15$. 
A

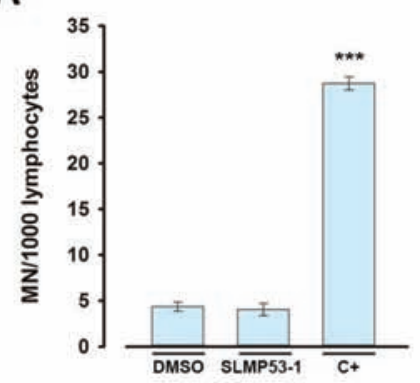

D
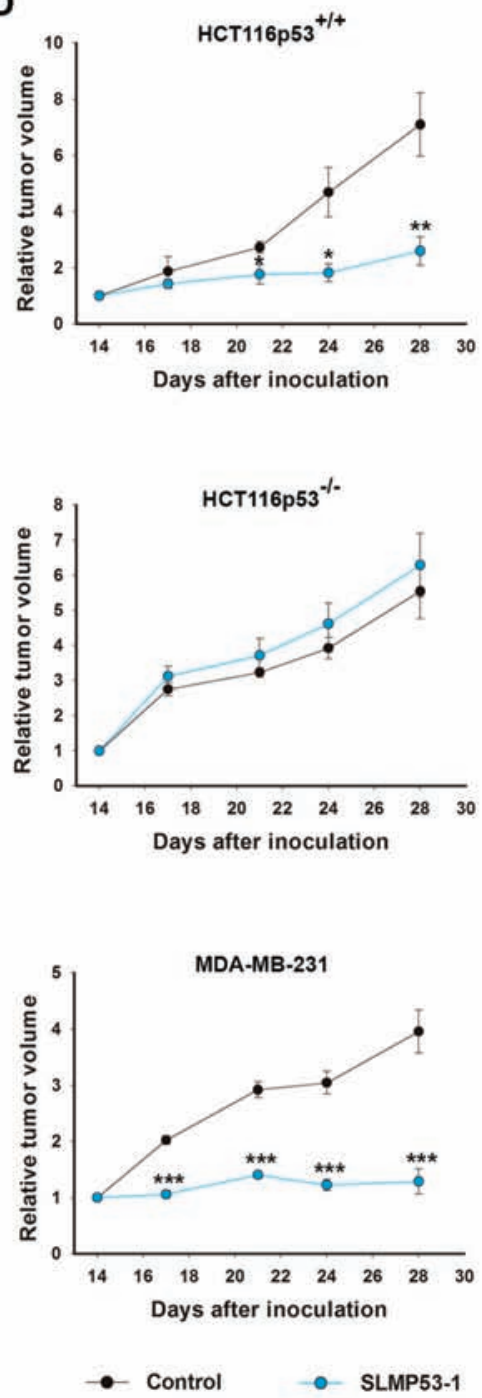

B

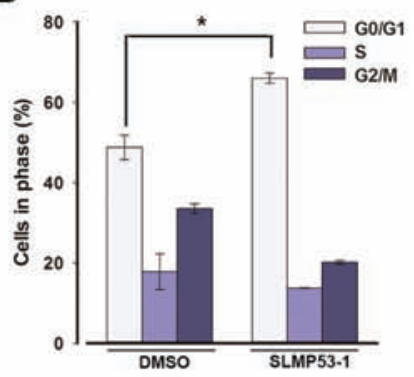

C

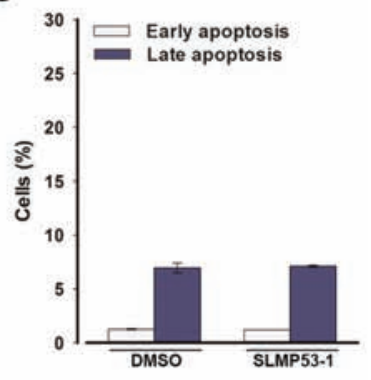

E
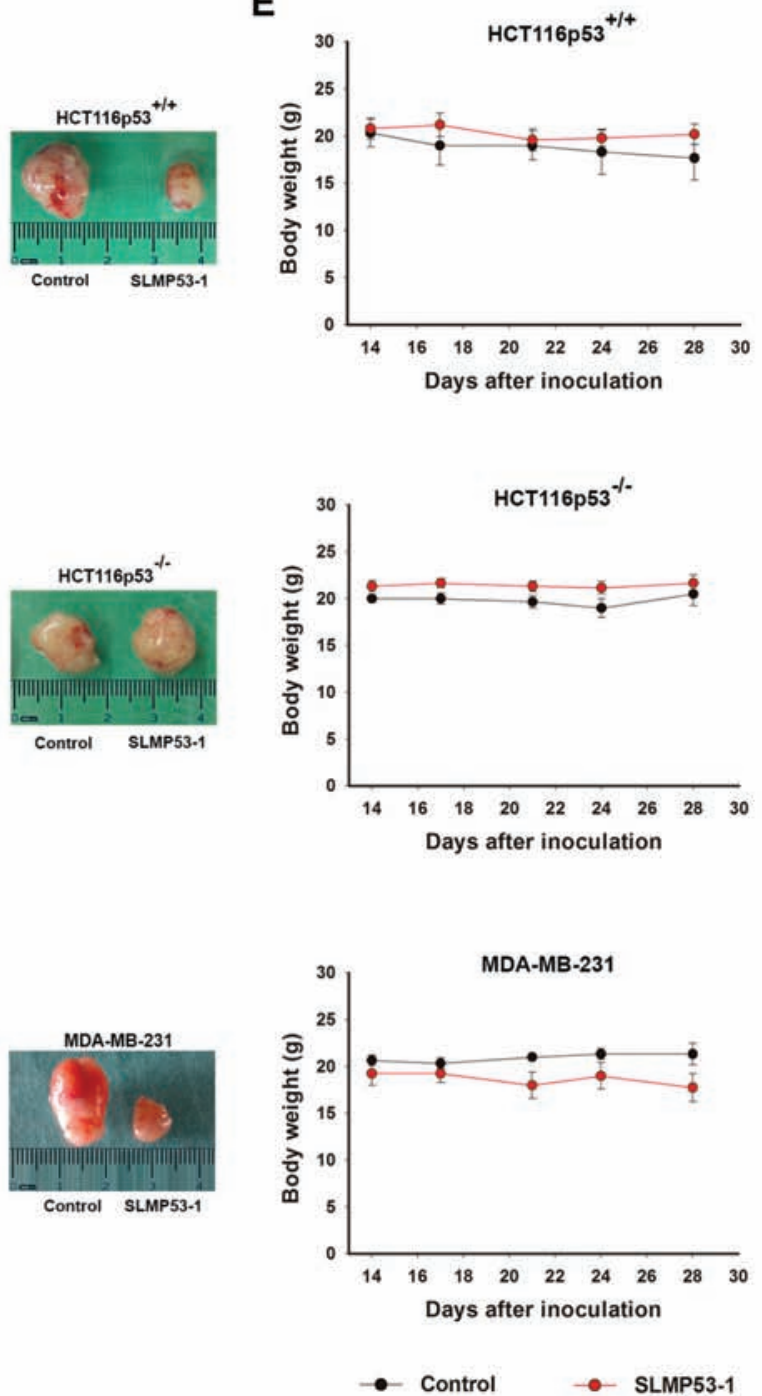

Figure 7: SLMP53-1, with no apparent in vitro toxicity, has potent in vivo antitumor activity. (A) Genotoxicity of $16 \mu \mathrm{M}$ SLMP53-1 by cytokinesis-block micronucleus (MN) assay after $72 \mathrm{~h}$ treatment in human lymphocyte cells. Cells treated with $1 \mu \mathrm{g} / \mathrm{mL}$ cyclophosphamide were used as positive control $(\mathrm{C}+)$; data are mean $\pm \operatorname{SEM}(n=3)$. (B) Cell cycle after $48 \mathrm{~h}$ with $42.4 \mu \mathrm{M}$ SLMP53-1 in MCF10A cells; data are mean $\pm \operatorname{SEM}(n=3)$. In A and B, values significantly different from DMSO only: $* * * p<0.001$. C. Apoptosis after $48 \mathrm{~h}$ with $42.4 \mu \mathrm{M}$ SLMP53-1 in MCF10A cells; data are mean $\pm \operatorname{SEM}(n=3)$; no significant differences between SLMP53-1 and DMSO only: $p>0.05$. (D) BALB/c nude mice carrying HCT116p53 $3^{+/+}$, HCT116p53 $3^{-/}$or MDA-MB-231 xenografts treated with $50 \mathrm{mg} / \mathrm{kg}$ SLMP53-1 or vehicle (control); values significantly different from control mice: ${ }^{*} p<0.05,{ }^{* *} p<0.01,{ }^{* * *} p<0.001$; representative pictures of control and SLMP53-1-treated tumors. (E) BALB/c mice body weight during SLMP53-1 treatment; no significant differences between control and SLMP53-1-treated mice: $p>0.05$. 
restored the wt-like sequence-specific DNA binding ability to mut p53R280K, with subsequent up-regulation of p53 target genes. Curiously, in mut p53R280K-expressing cells, the SLMP53-1-induced growth inhibition was only associated with apoptosis, and not with cell cycle arrest. These results highlight key genetic differences between tumor cells associated with distinct p53 status (wt/mut).
The pathophysiological relevance of the mitochondrial p53 function on apoptotic cell death has been emphasized in several studies [18]. In response to stress, a fraction of p53 translocates to mitochondria, where it binds with Bcl-2 family proteins inducing mitochondrial outer membrane permeabilization (MOMP), cyt $c$ release, and subsequent apoptosis [18].
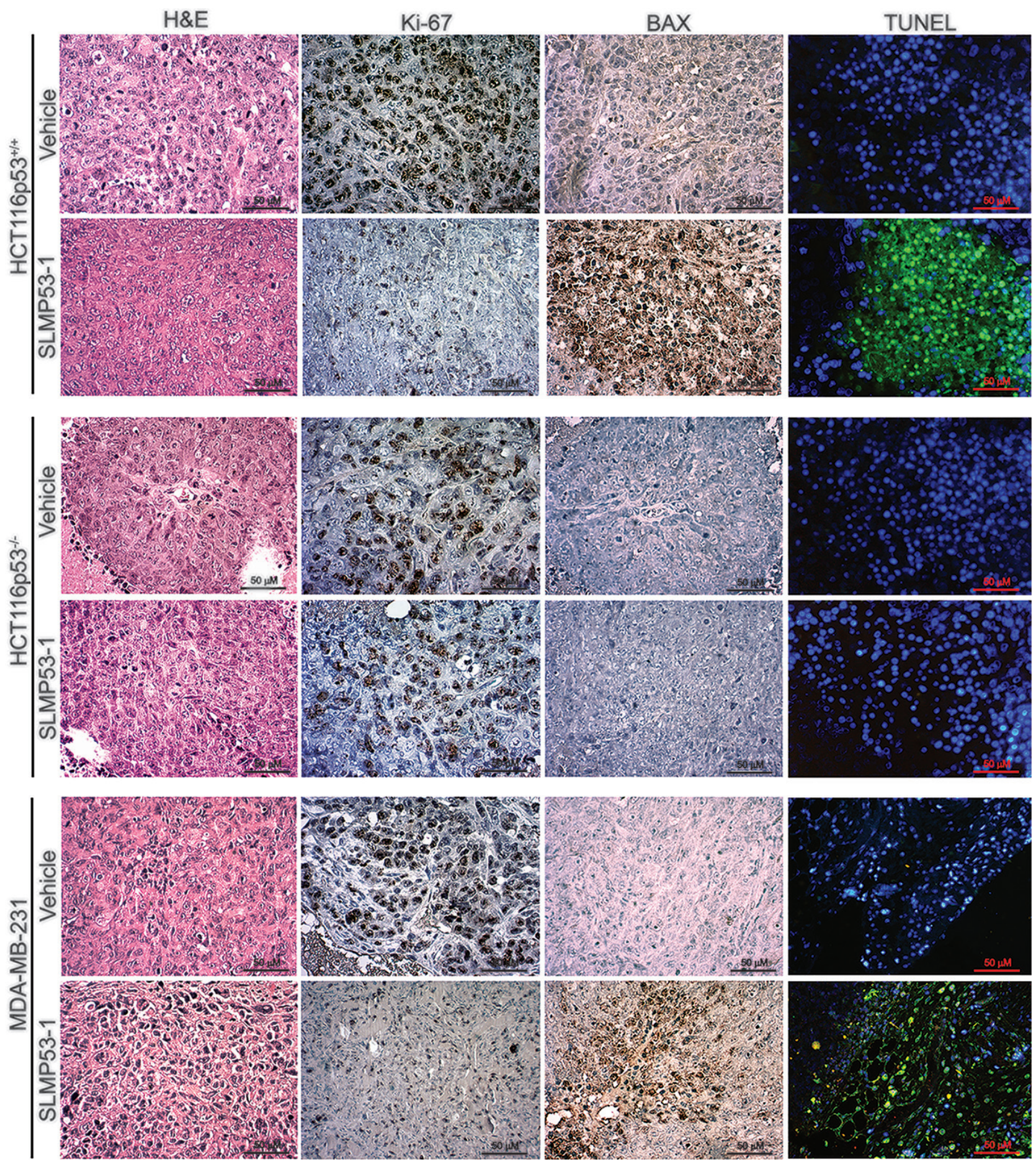

Figure 8: SLMP53-1 decreases cell proliferation and enhances apoptosis in human xenograft tumors. Representative images of Ki-67, BAX and DNA fragmentation detection in human HCT116p53 $3^{++}$, HCT116p53 $3^{-/}$and MDA-MB-231 xenograft tumor tissues inoculated in BALB/c nude mice treated with $50 \mathrm{mg} / \mathrm{kg}$ SLMP53-1 or vehicle (Scale bar = $50 \mu$ m; Magnification $400 \times$ ). 
The mitochondrial function of mut p53 is still unclear. Interestingly, mut p53 has been reported to localize constitutively at mitochondrial outer membrane due to its intrinsic cellular stabilization. Despite this, the mut p53 apoptotic activity is compromised by its inability to bind to Bcl-2 and trigger MOMP $[18,19]$. In this work, SLMP53-1 triggered a mitochondrial p53 apoptotic pathway in wt p53-expressing tumor cells, involving $\Delta \psi_{\mathrm{m}}$ dissipation, p53 and BAX mitochondrial translocation, as well as cyt $c$ release. Similar events were triggered by SLMP53-1 in mut p53R280K-expressing tumor cells, supporting the translocation of a functionally active mut p53 to mitochondria.

It is interesting to note that SLMP53-1 treatment induced a p53-dependent ROS generation, which may result from the stimulation of both pro-oxidant and mitochondrial p53 functions. Actually, SLMP53-1 enhances the expression of $B A X$ and PUMA, which besides a connection with the p53 mitochondrial pathway are also strongly involved in its pro-oxidant function [20].

Collectively, the results obtained indicate that SLMP53-1 is a "double hit" reactivator of p53-mediated apoptosis, stimulating both the transcription-dependent and mitochondrial-mediated p53 functions.

Considered the main cause of morbidity and mortality in cancer patients, tumor cell invasion and metastization are central issues in cancer treatment $[21,22]$. The pivotal role of p53 in the prevention of epithelial-mesenchymal transition and migration is widely recognized [22]. Accordingly, mut p53 has been associated to prometastatic functions not only due to the loss of p53 function, but also to the GOF related to p63 inhibition, a well-known suppressor of tumorigenesis and metastasis [22]. Low doses of SLMP53-1 potently inhibited the migration of wt/mut $\mathrm{p} 53$-expressing cells, which sustains the reactivation of wt p53, as well as of mut p53 through reestablishment of its wt function and possible inhibition of its GOF.

Drug combination may minimize drug side effects, while increasing tumor suppressor activity [23]. Since the majority of conventional chemotherapeutics, as etoposide and doxorubicin, depend on a functional p53 pathway, combination with p53 reactivators is expected to enhance their efficacy. Indeed, at low doses, SLMP53-1 showed p53-dependent synergistic effects with both chemotherapeutic agents in wt/mut p53-expressing tumor cells. Therefore, combination of SLMP53-1 with chemotherapeutics revealed great therapeutic potential, particularly against multidrug-resistant tumor cells, like triple-negative breast cancers.

The toxicity of standard chemotherapeutics remains a therapeutically limiting problem. Herein, SLMP53-1 was shown to be non-genotoxic. Additionally, despite activating wt p53, at the $\mathrm{GI}_{50}$ concentration obtained in tumor cells, SLMP53-1 was not cytotoxic against wt p53-expressing normal MCF10A cells. The minimal cytotoxic effects of $\mathrm{p} 53$ reactivators on normal cells have been attributed to their lower susceptibility to apoptotic stimuli when compared to tumor cells with a constitutive activation of a DNA damage signaling pathway [24-26]. This leads normal cells to respond to $\mathrm{p} 53$ reactivators with cell cycle arrest (cytostatic effect), instead of cell death (cytotoxic effect) $[27,28]$. Actually, this was observed in normal cells with SLMP53-1 at $3 \times \mathrm{GI}_{50}$ concentration used in tumor cells. SLMP53-1 can thus be exploited in p53-based cyclotherapy, in which normal cells are protected from the cytotoxicity of chemotherapeutics by induction of cell cycle arrest.

Assays in xenograft mice models reinforced the p53-dependent in vivo antitumor activity of SLMP53-1. In fact, SLMP53-1 potently suppressed the growth of wt p53- and mut p53R280K-expressing tumors through inhibition of proliferation and induction of apoptosis, without interfering with the growth of p53-null tumors. Additionally, SLMP53-1 had no apparent toxic side effects on tissues most commonly affected by chemotherapy, such as kidneys, liver and bone marrow.

In conclusion, several evidences are provided in this work supporting the anticancer therapeutic potential of SLMP53-1, both alone and combined with conventional chemotherapeutics. To our knowledge, this is the first report of a pharmacological reactivator of mut p53R280K. Besides its potential applicability in cancer therapy, SLMP53-1 is a starting point for the development of new effective derivatives targeting mut p53s.

\section{MATERIALS AND METHODS}

\section{Chemical synthesis of SLMP53-1 and its enantiomer}

All reagents and solvents were obtained from commercial suppliers and used without further purification. Melting point was determined using a Kofler camera Bock monoscope M. The infrared spectra were collected on a Shimadzu IRAffinity-1 FTIR infrared spectrophotometer. Only noteworthy IR absorptions $\left(\mathrm{cm}^{-1}\right)$ are listed. Microanalyses were performed in a Thermo Scientific TM FLASH 2000 Series CHNS/O analyzer and are within $\pm 0.5 \%$ of theoretical values. Analysis Merck Silica Gel 60 F254 plates were used as analytical thin layer chromatography; flash chromatography was performed on Merck Silica Gel (200-400 mesh). Optical rotations were determined in a Perkin-Elmer $241 \mathrm{MC}$ polarimeter at rt. ${ }^{1} \mathrm{H}$ and ${ }^{13} \mathrm{C}$ NMR spectra were recorded on a Bruker $400 \mathrm{MHz}$ Ultra-Shield. ${ }^{1} \mathrm{H}$ nuclear magnetic resonance spectra were recorded at $400 \mathrm{MHz}$. Carbon nuclear magnetic resonance spectra were recorded at $100 \mathrm{MHz} .{ }^{1} \mathrm{H}$ and ${ }^{13} \mathrm{C}$ NMR chemical shifts are reported in $\delta(\mathrm{ppm})$ referenced to the solvent 
used and the proton coupling constants $\mathrm{J}$ in hertz $(\mathrm{Hz})$ (Supplementary Figure 1). Spectra were assigned using appropriate COSY, DEPT and HMQC sequences.

Chemical Synthesis of SLMP53-1 (Figure 1A): 2-Acetyl-benzoic acid (0.19 g, $1.16 \mathrm{mmol}, 1.1$ eq.) was added to a stirred solution of $(S)$-tryptophanol $(0.2 \mathrm{~g}, 1.05$ mmol, 1.0 eq.) in $10 \mathrm{~mL}$ of toluene. The mixture was heated at reflux under inert atmosphere using Dean-Stark conditions during $16 \mathrm{~h}$. The solvent was removed under reduced pressure and the residue obtained was purified by flash chromatography (Ethyl Acetate/n-Hexane 2:1). The product was obtained as a white solid ( $81 \%$ yield) after recrystallization in Ethyl Acetate/n-Hexane. SLMP53-1: IR (KBr): $3283(\mathrm{~N}-\mathrm{H}) ; 1697(\mathrm{C}=\mathrm{O}) \mathrm{cm}^{-1}$; mp: 182 $184{ }^{\circ} \mathrm{C} ;[\alpha]^{20}{ }_{\mathrm{D}}+23.7$ (c $\left.0.43 \mathrm{~g} / 100 \mathrm{ml}, \mathrm{CH}_{2} \mathrm{Cl}_{2}\right) ;{ }^{1} \mathrm{H} \mathrm{NMR}$ $\left(\right.$ DMSO-d $\left._{6}\right) \delta 10.92(\mathrm{~s}, 1 \mathrm{H}, \mathrm{NH}), 7.74-7.65(\mathrm{~m}, 3 \mathrm{H}$, H-Ar), 7.59 (m, 2H, H-Ar), 7.38 - 7.34 (m, 2H, H-Ar), 7.08 (t, J = 7.1 Hz, 1H, H-Ar), 7.01 (t, J $=7.4 \mathrm{~Hz}, 1 \mathrm{H}$, $\mathrm{H}-\mathrm{Ar}), 4.41-4.29\left(\mathrm{~m}, 2 \mathrm{H}, \mathrm{CH}\right.$ and $\left.\mathrm{OCH}_{2}\right), 4.14(\mathrm{dd}$, $\left.\mathrm{J}=8.0,6.1 \mathrm{~Hz}, 1 \mathrm{H}, \mathrm{OCH}_{2}\right), 3.25(\mathrm{dd}, \mathrm{J}=14.5,5.1 \mathrm{~Hz}$, $1 \mathrm{H}, \mathrm{CH}_{2}$-indole), $3.12\left(\mathrm{dd}, \mathrm{J}=14.6,8.1 \mathrm{~Hz}, 1 \mathrm{H}, \mathrm{CH}_{2}-\right.$ indole), 1.67 (s, $\left.3 \mathrm{H}, \mathrm{CH}_{3}\right) ;{ }^{13} \mathrm{C}$ NMR (DMSO-d $\left._{6}\right) \delta 173.76$ $(\mathrm{C}=\mathrm{O}), 147.55(\mathrm{Cq}), 136.63(\mathrm{Cq}), 133.93(\mathrm{CH}-\mathrm{Ar})$, $131.40(\mathrm{Cq}), 130.81(\mathrm{CH}-\mathrm{Ar}), 127.85(\mathrm{Cq}), 124.04(\mathrm{CH}-$ Ar), 123.87 (CH-Ar), 123.25 (CH-Ar), 121.49 (CH-Ar), 118.86 (CH-Ar), 118.70 (CH-Ar), 111.88 (CH-Ar), 110.60 $(\mathrm{Cq}), 98.87(\mathrm{Cq}), 74.65\left(\mathrm{OCH}_{2}\right), 55.95(\mathrm{CH}), 30.84\left(\mathrm{CH}_{2}\right)$, $22.79\left(\mathrm{CH}_{3}\right)$; Anal. calcd. for $\mathrm{C}_{20} \mathrm{H}_{18} \mathrm{~N}_{2} \mathrm{O}_{2} \cdot 0.15 \mathrm{H}_{2} \mathrm{O}$ : $\mathrm{C}$ 74.81, H 5.67, N 8.73, found: C 74.86, H 5.67, N 8.75.

Chemical Synthesis of SLMP53-1 enantiomer (Figure 1A): Following the same procedure used for the synthesis of SLMP53-1, to a solution of $(R)$-tryptophanol $(0.1 \mathrm{~g}, 0.53 \mathrm{mmol})$ in toluene $(15 \mathrm{~mL})$ was added 2-acetylbenzoic acid $(0.10 \mathrm{~g}, 0.58 \mathrm{mmol})$. The product was obtained as a white solid (76\% yield) after recrystallization in EtOAc/n-Hexane. $[\alpha]^{20}{ }_{\mathrm{D}}-27.1$ (c $0.43 \mathrm{~g} / 100 \mathrm{ml}, \mathrm{CH}_{2} \mathrm{Cl}_{2}$ ) ${ }^{1} \mathrm{H}$ NMR spectra was found to be identical to the one obtained for compound SLMP53-1.

\section{Plasmids and compounds}

The yeast expression vector pLS89-(TRP1) encoding human wt p53 under GAL1-10 inducible promoter (kindly provided by Dr. Richard Iggo; Swiss Institute for Experimental Cancer Research, Switzerland), and pTS76-(LEU2) encoding human mut p53R280K or mut p53Y220C under ADH1 constitutive promoter (kindly provided by Dr. Gilberto Fronza; IST Istituto Nazionale per la Ricerca sul Cancro, Genoa, Italy), were used.

PRIMA-1, doxorubicin and PFT- $\alpha$ were purchased from Sigma-Aldrich, Phikan083 from Tocris and etoposide from Calbiochem. All tested compounds were dissolved in dimethyl sulfoxide (DMSO; Sigma-Aldrich).

\section{Yeast-based screening assay}

Saccharomyces cerevisiae (strain CG379) was transformed using the standard lithium acetate method [8]. For expression of human proteins, cells (routinely grown in minimal selective medium) were diluted to $0.05 \mathrm{OD}_{600}$ in induction selective medium containing $2 \%$ $(\mathrm{w} / \mathrm{w})$ galactose, $1 \%(\mathrm{w} / \mathrm{w})$ raffinose, $0.7 \%(\mathrm{w} / \mathrm{w})$ yeast nitrogen base without amino acids from Difco, and a mixture of all the amino acids required for yeast growth $(50 \mu \mathrm{g} / \mathrm{mL}$ ) except leucine (for pTS76) or tryptophan (for pLS89). Cells transformed with the empty vector (pTS76 or pLS89) were used as control yeast. Yeast cells were incubated at $30^{\circ} \mathrm{C}$ under continuous orbital shaking (200 r.p.m.), in the presence of $0.1-50 \mu \mathrm{M}$ of compounds or $0.1 \%$ DMSO only, for approximately $30 \mathrm{~h}$ (time required by control yeast, incubated with DMSO only, to achieve $\left.0.4 \mathrm{OD}_{600}\right)$. In the experiments with PFT- $\alpha$, yeast cells expressing wt/mut p53 were incubated with $5 \mu \mathrm{M}$ PFT- $\alpha$ alone and combined with $10 \mu \mathrm{M}$ SLMP53-1, or DMSO only for approximately $30 \mathrm{~h}$. Yeast growth was analysed by counting the number of colony-forming units (CFU), after 2 days incubation at $30^{\circ} \mathrm{C}$, on Sabouraud Dextrose Agar from Liofilchem.

\section{Yeast cell cycle analysis}

Yeast cell cycle progression was analyzed basically as described [29]. Briefly, $1 \times 10^{7}$ cells were fixed in $70 \%(\mathrm{v} / \mathrm{v})$ ethanol, incubated with $250 \mu \mathrm{g} / \mathrm{mL}$ RNase A (Sigma-Aldrich) and $1 \mathrm{mg} / \mathrm{mL}$ Proteinase K (Sigma-Aldrich), followed by $10 \mu \mathrm{M}$ Sytox Green Nucleic Acid from Invitrogen and flow cytometry analysis.

\section{Human cell lines and growth conditions}

Human colon adenocarcinoma HCT116 cell line expressing wt p53 (HCT116 p53 $3^{+/+}$) and its isogenic derivative in which full-length $\mathrm{p} 53$ has been knocked out

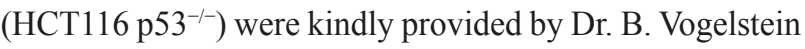
(The Johns Hopkins Kimmel Cancer Center, Baltimore, MD, USA); human breast cancer MDA-MB-231, human hepatoma $\mathrm{HuH}-7$, and non-tumorigenic human breast epithelial MCF10A cell lines were from ATCC. All tumor cell lines were routinely cultured in RPMI-1640 medium with ultraglutamine from Lonza supplemented with $10 \%$ fetal bovine serum (FBS) from Gibco. MCF10A cell line was cultured in DMEM F12 from Lonza supplemented with MEGM SingleQuot Kit Suppl. \& Growth Factors from Lonza. All cell lines were maintained in a humidified incubator at $37^{\circ} \mathrm{C}$ with $5 \% \mathrm{CO}_{2}$.

\section{Sulforhodamine B (SRB) assay}

Human cell lines were incubated in 96-well plates, at a final density of $5.0 \times 10^{3}$ cells/well (for HCT116 and HuH-7 
cell line), and of $1.0 \times 10^{4}$ cells/well (for MDA-MB-231 and MCF10A cell line), for $24 \mathrm{~h}$. Cells were thereafter treated with serial dilutions of compound (from 1.85 to $150 \mu \mathrm{M}$ ) for $48 \mathrm{~h}$. The effect of compounds on in vitro growth was analyzed using the SRB assay as described [10, 30]. The solvent (DMSO; maximum concentration used of $0.25 \%$ ) was included as control.

For combined treatments, HCT116 p53 ${ }^{+/+}$, HCT116 p53 ${ }^{-/-}$and MDA-MB-231 cell lines were treated with the $\mathrm{GI}_{10}$ concentration of SLMP53-1 (or DMSO only) and increasing concentrations of doxorubicin $(9.38-750 \mathrm{nM})$ or etoposide $(0.38-6.00 \mu \mathrm{M})$. The effect of combined treatments on cell growth was analyzed after $48 \mathrm{~h}$ incubation, using the SRB assay, and is expressed by the combination index $(Q)$, calculated as reported [30], which indicates: $Q<0.85$, antagonism; $0.85<Q<1.15$ additive effect; $Q>1.15$, synergy.

\section{Analysis of cell cycle and apoptosis in human cell lines}

HCT116, MDA-MB-231 and MCF10A cell lines were incubated in 6-well plates, at a final density of $1.5 \times 10^{5}$ cells/well (for HCT116 cell line) and $2.3 \times 10^{5}$ cells/well (for MDA-MB-231 and MCF10A cell lines), for $24 \mathrm{~h}$. Cells were thereafter treated with SLMP53-1 or DMSO only for $24 \mathrm{~h}$. For cell cycle analysis, cells were stained with propidium iodide (PI; Sigma-Aldrich) followed by flow cytometric analysis, as described [30]. For apoptosis analysis, cells were analyzed by flow cytometry using the Annexin V-FITC Apoptosis Detection Kit I from BD Biosciences according to the manufacturer's instructions; synergistic effects of combined treatments between the $\mathrm{GI}_{10}$ concentration of SLMP53-1 (or DMSO only) and $0.19 \mu \mathrm{M}$ doxorubicin or $0.38 \mu \mathrm{M}$ etoposide, in MDA-MB-231 cell lines, were analyzed (determination of $Q$ value) as described in the SRB assay.

\section{Western blot analysis}

Whole protein extracts (from yeast and human cells), and mitochondrial/cytosolic fractions from human cell lines were prepared as described [30]. Western blot analysis was performed as described [30] using a mouse monoclonal anti-p53 (DO-1), anti-MDM2 (SMP14), anti-BAX (2D2), anti-PUMA (B-6), anti-PARP (C2-10), and anti-cytochrome $c$ (A8) antibodies followed by an anti-mouse horseradish-peroxidase (HRP)-conjugated secondary antibody. For p21 detection, membranes were probed with a rabbit polyclonal anti-p21 (C-19) antibody, followed by an anti-rabbit HRP-conjugated secondary antibody. For loading control, membranes were stripped and reprobed with a mouse monoclonal anti-yeast phosphoglycerate kinase (Pgk1p) or anti-GAPDH (6C5) antibodies. For analysis of mitochondrial and cytosolic fractions, membranes were reprobed with the loading controls mouse monoclonal anti-COX IV (F-8) and anti-GAPDH (6C5) antibodies, respectively. With the exception of anti-Pgk1p (Alfagene), all antibodies were purchased from Santa Cruz Biotechnology. Western blots presented are representative of three independent experiments.

\section{Dual-luciferase reporter assay in human tumor cell lines}

Dual-luciferase reporter assay was performed basically as reported [29, 31]. Briefly, about $5 \times 10^{4}$ cells/well of HCT116 tumor cell line were incubated in 24-well plates for $24 \mathrm{~h}$. Cells were thereafter transfected at approximately $80 \%$ confluence using the Myrus LT- 1 reagent, and according to the manufacturer's instructions. Specifically, $350 \mathrm{ng}$ of the reporter vectors containing either the p21 (pGL3-1138) or the MDM2 (pGL3-MDM2) promoter were used along with $50 \mathrm{ng}$ of the control pRLSV40 plasmid introduced to normalize the transfection efficiency. After transfection, cells were treated with the $\mathrm{GI}_{50}$ and $2 \times \mathrm{GI}_{50}$ concentration of SLMP53-1 (or DMSO only), for $16 \mathrm{~h}$. Cells were harvested, and the luciferase assay was carried out using the dual-luciferase reagent. The p53 transcriptional activity is directly proportional to the luciferase activity (measured by the emitted light intensity) as described [29].

\section{RNA extraction and quantitative RT-PCR (qPCR)}

Total RNA from tumor cell lines was extracted using the RNeasy Kit (Qiagen). About $1 \mu \mathrm{g}$ of RNA was used for cDNA synthesis using M-MuLV reverse transcritptase and RevertAid cDNA Synthesis kit (ThermoFisher) in $20 \mu \mathrm{L}$ final volume, and following manufacturer's instructions. qPCR assays were performed in a 384-well plate format on a CFX Touch Real-Time PCR Detection System (Bio-rad), starting with $25 \mathrm{ng}$ of cDNA, as previously described [32]. The 2X KAPA SYBR ${ }^{\circledR}$ FAST qPCR Kit (Kapa Biosystems) and specific primers, purchased from Eurofins (MWG), were employed. GAPDH, B2M and $A C T B$ were used as reference genes.

\section{TransAM assay}

About $1.5 \times 10^{6}$ cells of MDA-MB-231 cell line were incubated in T-75 flasks for $24 \mathrm{~h}$. Cells were thereafter treated with $2 \times \mathrm{GI}_{50}$ and $3 \times \mathrm{GI}_{50}$ concentration of SLMP53-1 (or DMSO only) for $24 \mathrm{~h}$. Nuclear protein extracts were obtained using the Nuclear Extract Kit from Active Motif, and the protein concentration was measured using NanoDrop 1000 from Thermo scientific. The p53 DNA binding ability was evaluated using the TransAM p53 Transcription Factor Assay Kit from Active Motif, according to the manufacturer's instructions. Briefly, equal amount of total nuclear protein was loaded into a 96-well plate coated with an immobilized oligonucleotide containing a p53 consensus binding site. The amount of bound p53 protein was quantified using an anti-p53 antibody followed by a HRP-conjugated secondary 
antibody. The HRP signal was measured after addition of a manufacturer's substrate, using the Bio-Tek Synergy HT plate reader at $450 \mathrm{~nm}$. A nuclear extract of wt p53-expressing MCF-7 cells treated with $\mathrm{H}_{2} \mathrm{O}_{2}$ was used as kit positive control.

\section{Transfection of p53 siRNA}

MDA-MB-231 cells were transfected with $100 \mathrm{nM}$ of small interfering RNAs (siRNAs) against p53 (SMARTpool p53) and negative nonspecific siRNAs (Non-targeting Pool) from Thermo Scientific/Dharmacon using Lipofectamine 2000 (Invitrogen), following the manufacturer's instructions. After $24 \mathrm{~h}$ transfection, cells were treated with $\mathrm{GI}_{50}$ concentration of SLMP53-1 (or DMSO only) for $24 \mathrm{~h}$.

\section{Analysis of $\Delta \psi_{\mathrm{m}}$ dissipation and ROS generation}

Analyses of $\Delta \psi_{\mathrm{m}}$ dissipation and ROS generation were performed as previously reported [30]. Briefly, about $1.5 \times 10^{5}$ cells/well (for HCT116 cell line) and $2.3 \times 10^{5}$ cells/well (for MDA-MB-231 cell line) were incubated in 6-well plates for $24 \mathrm{~h}$. Cells were thereafter treated with the $\mathrm{GI}_{50}$ concentration of SLMP53-1 (or DMSO only) for $8 \mathrm{~h}$ (for HCT116 cell line) or $16 \mathrm{~h}$ (for MDA-MB-231 cell line) in $\Delta \psi_{\mathrm{m}}$ analysis, and for $24 \mathrm{~h}$ in ROS analysis. Then, cells were stained with $5 \mu \mathrm{M}$ Cell-ROX Green Reagent from Life Technologies (in ROS analysis) or with $1 \mathrm{nM}$ $\mathrm{DiOC}_{6}(3)$ from Alfagene (in $\Delta \psi_{\mathrm{m}}$ analysis) for $30 \mathrm{~min}$ at $37^{\circ} \mathrm{C}$; followed by flow cytometry analysis.

\section{In vitro migration assays}

Cell migration was analyzed using the Wound Healing Scratch assay (as described in [33]) and the QCM 24-Well Fluorimetric Chemotaxis Cell Migration Kit (8 $\mu \mathrm{m})$, from Merck Millipore. In the Wound Healing Scratch assay, about $5 \times 10^{5}$ cells/well of HCT116 p53 $3^{+/+}$and MDA-MB-231 cell lines were grown to confluence in 6-well plates for $24 \mathrm{~h}$. Using a sterile $200 \mu \mathrm{L}$ tip, a fixed-width wound was created in the cell monolayer and the $\mathrm{GI}_{10}$ concentration of SLMP53-1 (or DMSO only) was added to medium. Cells were thereafter photographed using the Moticam 5.0MP camera with Motic's AE2000 inverted microscope with 400x magnification at different time-points of treatment until complete closure of the wound. In the QCM 24-Well Fluorimetric Chemotaxis Cell Migration Kit $(8 \mu \mathrm{m})$, about $0.5 \times 10^{6}$ cells $/ \mathrm{mL}$ of HCT116 p53 ${ }^{+/+}$and MDA-MB-231 cell lines were prepared in serum free RPMI 1640 treated with the $\mathrm{GI}_{25}$ (for HCT116 p53 ${ }^{+/+}$cell line) or $\mathrm{GI}_{50}$ (for MDA-MB-231 cell line) of SLMP53-1 (or DMSO only), and incubated for $24 \mathrm{~h}$ or $8 \mathrm{~h}$, respectively. The prepared cell suspensions were distributed in 24-well plates (300 $\mu \mathrm{L} /$ insert), followed by addition of $500 \mu \mathrm{L}$ medium containing $10 \%$ FBS to the lower chamber. Cells that migrated through the $8 \mu \mathrm{m}$ pore membranes were eluted, lysed and stained with a green-fluorescence dye that binds to cellular nucleic acids. The number of migrated cells is proportional to the fluorescence signal measured using the Bio-Tek Synergy HT plate reader at 480/520 $\mathrm{nm}$ (ex/em).

\section{Genotoxicity studies by micronucleus assay}

Genotoxicity was analyzed by cytokinesis-block micronucleus assay in lymphocytes as described [34]. Fresh peripheral blood samples were collected from healthy volunteers into heparinized vacutainers. Blood samples, suspended in RPMI medium supplemented with 10\% FBS, were treated with the $\mathrm{GI}_{50}$ concentration of SLMP53-1, DMSO only or $1 \mu \mathrm{g} / \mathrm{mL}$ cyclophosphamide (known mutagenic agent; positive control; Sigma-Aldrich) for $44 \mathrm{~h}$. Cells were thereafter treated with $3 \mu \mathrm{g} / \mathrm{mL}$ cytochalasin B (cytokinesis preventive; Sigma-Aldrich) for $28 \mathrm{~h}$. Lymphocytes were isolated by density gradient separation (Histopaque-1077 and -1119; Sigma-Aldrich,), fixed in 3:1 methanol/glacial acetic acid, and stained with Wright stain (Sigma-Aldrich). For each sample, 1000 binucleated lymphocytes were blindly scored using a Leica light optical microscope (Wetzlar); the number of micronuclei per 1000 binucleated lymphocytes was recorded.

\section{In vivo antitumor and toxicity assays}

Animal experiments were conducted according to the European Council Directives on Animal Care and to the National Authorities. The BALB/c Nude mice and Wistar rats were purchased from Charles-River Laboratories and housed under pathogen free conditions in individual ventilated cages. For toxicity assays, Wistar rats were treated with $50 \mathrm{mg} / \mathrm{kg}$ SLMP53-1, vehicle (DMSO) or saline solution (control) by intraperitoneal injection, twice a week during two weeks. After the four administrations, samples of blood and organs (kidneys, liver, heart and lungs) were collected for toxicological analysis. Each group was composed of five animals. Xenograft tumor assays were performed with HCT116p53 ${ }^{+/+}$, HCT116p53 $3^{-/}$and MDA-MB-231 human tumor cell lines. Briefly, $1 \times 10^{6} \mathrm{HCT} 116$ cells (in PBS) or $5 \times 10^{6}$ MDA-MB-231 cells (in PBS/BD Matrigel Matrix High Concentration, 1:1; BD Biosciences) were inoculated subcutaneously in the dorsal flank of each mice. Tumor dimensions were assessed by caliper measurement and their volumes were calculated [tumor volume $=\left(\right.$ length $\times$ width $\left.^{2}\right) / 2$ ]. Treatment was started when tumors reached volumes of approximately $100 \mathrm{~mm}^{3}$ (which occurred 14 days after the grafts). Mice were then treated twice a week with $50 \mathrm{mg} / \mathrm{kg}$ SLMP53-1 or vehicle (control) by intraperitoneal injection during two weeks. Tumor volumes and body weights were monitored 
twice a week until the end of the treatment. Animals were sacrificed by cervical dislocation at the end of the study. After sacrifice, tumors were removed and photographed. Human endpoints were established namely euthanasia in case of tumors reached $1500 \mathrm{~mm} 3$, or if the animals presented any signs of morbidity. The following number of animals was used: HCT116p53 $3^{+/+}$and HCT116p53 $53^{-/}$cell lines (Control-6, Treatment-6), MDA-MB-231 (Control-6, Treatment-6).

\section{Immunohistochemistry}

Tumor tissues were fixed in $10 \%$ formalin, embedded in paraffin, sectioned at $4 \mu \mathrm{m}$, and stained with hematoxylin and eosin ( $\mathrm{H} \& \mathrm{E}$ ) or antibodies, following standard methodologies. Briefly, after deparaffination and rehydration, antigen retrieval was performed by boiling the sections for $20 \mathrm{~min}$ in $10 \mathrm{mM}$ citrate buffer ( $\mathrm{pH} \mathrm{6.0)}$ ). The slices were then held for $20 \mathrm{~min}$ at room temperature. After dewaxing and blocking the endogenous peroxidases with UltraVision Hydrogen Peroxide Block, sections were treated with UltraVision Protein Block solution, both from Lab Vision Thermo Scientific. Incubation with primary anti-Ki-67 (SP6) and anti-BAX (6A7) antibodies, from Pierce Thermo Scientific, was performed for $2 \mathrm{~h}$, at room temperature. Immunostaining was carried out using the UltraVision Quanto Detection System HRP DAB kit, from Lab Vision Thermo Scientific, according to the manufacturer's instructions. Tissue sections were counterstained with Gill's hematoxylin from Thermo Scientific, dehydrated, clarified and mounted. The primary antibody was replaced by $10 \%$ non-immune serum for negative controls. Finally, images were obtained using the Motic's AE2000 inverted microscope $(400 \times$ magnification) with the Moticam 5.0 MP camera.

\section{TUNEL assay}

TUNEL assay was performed using the in situ Cell Death Detection Kit Fluorescein from Roche, according to the manufacturer's instructions. Briefly, after deparaffination and rehydration, tissues sections were treated for $20 \mathrm{~min}$ in $10 \mathrm{mM}$ citrate buffer ( $\mathrm{pH}$ 6.0) and incubated with TUNEL Reaction Mixture for $60 \mathrm{~min}$ at $37^{\circ} \mathrm{C}$ in the dark. Tissues were counterstained with DAPI $(0.1 \mu \mathrm{g} / \mathrm{mL})$. Images were obtained using an Eclipse E400 fluorescence microscope (Nikon), $400 \times$ magnification, with a Digital Sight camera system (Nikon DS-5Mc), carrying built-in software for image acquisition (Nikon ACT-2U).

\section{Flow cytometric data acquisition and analysis}

For the flow cytometric analysis, the AccuriTM C6 flow cytometer from BD Biosciences and the CellQuest software from BD Biosciences were used. For the identification and quantification of cell cycle phases the FlowJo software was used.

\section{Statistical analysis}

Data were analyzed statistically using the GraphPad software. Differences between means were tested for significance using the Student's $t$-test $\left({ }^{*} p<0.05 ; *^{*} p<0.01\right.$; *** $\left.p<0.001\right)$.

\section{ACKNOWLEDGMENTS AND FUNDINGS}

This work was funded by FEDER funds through the Operational Programme for Competitiveness Factors COMPETE, national funds provided by FCT - Foundation for Science and Technology under the Strategic Funding UID/Multi/04378/2013 (UCIBIO/REQUIMTE). We also thanks to iMed.ULisboa and to the FCT fellowships: J. Soares (SFRH/BD/78971/2011), L. Raimundo (PD/ BI/113926/2015), S. Gomes (SFRH/BD/96189/2013) and C. Bessa (SFRH/BD/87109/2012). M. M. M. Santos would like to acknowledge FCT, "Programa Operacional Potencial Humano" and the European Social Fund for the IF Program (IF/00732/2013).

\section{CONFLICTS OF INTEREST}

The authors declare no conflicts of interest.

\section{REFERENCES}

1. Khoo KH, Verma CS, Lane DP. Drugging the p53 pathway: understanding the route to clinical efficacy. Nat Rev Drug Discov. 2014; 13:217-236.

2. Zawacka-Pankau J, Selivanova G. Pharmacological reactivation of p53 as a strategy to treat cancer. J Intern Med. 2015; 277:248-259.

3. Girardini JE, Marotta C, Del Sal G. Disarming mutant p53 oncogenic function. Pharmacol Res. 2014; 79:75-87.

4. Muller PA, Vousden KH. Mutant p53 in cancer: new functions and therapeutic opportunities. Cancer Cell. 2014; 25:304-317.

5. Bykov VJ, Wiman KG. Mutant p53 reactivation by small molecules makes its way to the clinic. FEBS Lett. 2014; 588: 2622-2627.

6. Johnson WD, Muzzio M, Detrisac CJ, Kapetanovic IM, Kopelovich L, McCormick DL. Subchronic oral toxicity and metabolite profiling of the p53 stabilizing agent, CP31398, in rats and dogs. Toxicology. 2011; 289:141-150.

7. Petitjean A, Mathe E, Kato S, Ishioka C, Tavtigian SV, Hainaut P, Olivier M. Impact of mutant p53 functional properties on TP53 mutation patterns and tumor phenotype: lessons from recent developments in the IARC TP53 database. Hum Mutat. 2007; 28:622-629.

8. Leão M, Gomes S, Soares J, Bessa C, Maciel C, Ciribilli Y, Pereira C, Inga A, Saraiva L. Novel simplified yeast-based assays of regulators of p53-MDMX interaction and p53 transcriptional activity. FEBS J. 2013; 280:6498-6507. 
9. Boeckler FM, Joerger AC, Jaggi G, Rutherford TJ, Veprintsev DB, Fersht AR. Targeted rescue of a destabilized mutant of p53 by an in silico screened drug. Proc Natl Acad Sci USA. 2008; 105:10360-10365.

10. Soares J, Pereira NA, Monteiro A, Leão M, Bessa C, Dos Santos DJ, Raimundo L, Queiroz G, Bisio A, Inga A, Pereira C, Santos MM, Saraiva L. Oxazoloisoindolinones with in vitro antitumor activity selectively activate a p53pathway through potential inhibition of the p53-MDM2 interaction. Eur J Pharm Sci. 2015; 66C:138-147.

11. Pereira NAL, Sureda FX, Esplugas R, Perez M, Amat M, Santos MM. Tryptophanol-derived oxazolopiperidone lactams: identification of a hit compound as NMDA receptor antagonist. Bioorg Med Chem Lett. 2014; 24:3333-3336.

12. Pereira NAL, Sureda F, Turch M, Amat M, Bosch J, Santos MM. Synthesis of phenylalaninol-derived oxazolopyrrolidone lactams and evaluation as NMDA receptor antagonists. Monatsh Chem Chem Mon. 2013; 144:473-477.

13. Coutinho I, Pereira C, Pereira G, Gonçalves J, Côrte-Real M, Saraiva L. Distinct regulation of p53-mediated apoptosis by protein kinase $\mathrm{C} \alpha, \delta, \varepsilon$ and $\zeta$ : Evidence in yeast for transcription-dependent and -independent p53 apoptotic mechanisms. Exp Cell Res. 2011; 317:1147-1158.

14. Gudkov AV, Komarova EA. Prospective therapeutic applications of p53 inhibitors. Biochem Biophys Res Commun. 2005; 331:726-736.

15. Yu X, Vazquez A, Levine AJ, Carpizo DR. Allele-specific p53 mutant reactivation. Cancer Cell. 2012; 21:614-625.

16. Pereira NAL, Monteiro A, Machado M, Gut J, Molins E, Perry MJ, Dourado J, Moreira R, Rosenthal PJ, Prudêncio M, Santos MMM. Enantiopure indolizinoindolones with in vitro efficiency against blood- and liver-stage malaria parasites. Chem Med Chem. 2015; 10:2080-2089.

17. Russo D, Ottaggio L, Foggetti G, Masini M, Masiello P, Fronza G, Menichini P. PRIMA-1 induces autophagy in cancer cells carrying mutant or wild type p53. Biochim Biophys Acta. 2013; 1833:1904-1913.

18. Marchenko ND, Moll UM. The role of ubiquitination in the direct mitochondrial death program of p53. Cell Cycle. 2007; 6:1718-1723.

19. Wang F, Liu JF, Robbins D, Morris K, Sit A, Liu YY, Zhao Y. Mutant p53 exhibits trivial effects on mitochondrial functions which can be reactivated by ellipticine in lymphoma cells. Apoptosis. 2011; 16:301-310.

20. Puzio-Kuter AM. The Role of p53 in Metabolic Regulation. Genes Cancer. 2011; 2:385-391. doi: 10.1177/1947601911409738.

21. Etienne-Manneville S. Polarity proteins in migration and invasion. Oncogene. 2008; 27:6970-6980.

22. Muller PA, Vousden KH, Norman JC. p53 and its mutants in tumor cell migration and invasion. J Cell Biol. 2011; 192:209-218.

23. Teoh PJ, Chng WJ. p53 abnormalities and potential therapeutic targeting in multiple myeloma. Biomed Res Int. 2014; 2014:717919.
24. Vassilev LT. Small-molecule antagonists of p53-MDM2 binding: research tools and potential therapeutics. Cell Cycle. 2004; 3:419-421.

25. Berns K, Hijmans EM, Mullenders J, Brummelkamp TR, Velds A, Heimerikx M, Kerkhoven RM, Madiredjo M, Nijkamp W, Weigelt B, Agami R, Ge W, Cavet G, et al. A large-scale RNAi screen in human cells identifies new components of the p53 pathway. Nature. 2004; 428:431-437.

26. Tovar C, Rosinski J, Filipovic Z, Higgins B, Kolinsky K, Hilton H, Zhao X, Vu BT, Qing W, Packman K, Myklebost O, Heimbrook DC, Vassilev LT. Small-molecule MDM2 antagonists reveal aberrant p53 signaling in cancer: implications for therapy. Proc Natl Acad Sci. USA 2006; 103:1888-1893.

27. Carvajal D, Tovar C, Yang H, Vu BT, Heimbrook DC, Vassilev LT. Activation of p53 by MDM2 antagonists can protect proliferating cells from mitotic inhibitors. Cancer Res. 2005; 65:1918-1924.

28. Rao B, Lain S, Thompson AM. p53-Based cyclotherapy: exploiting the 'guardian of the genome' to protect normal cells from cytotoxic therapy. Br J Cancer. 2013; 109:2954-2958.

29. Leão M, Pereira C, Bisio A, Ciribilli Y, Paiva AM, Machado N, Palmeira A, Fernandes MX, Sousa E, Pinto M, Inga A, Saraiva L. Discovery of a new small-molecule inhibitor of p53-MDM2 interaction using a yeast-based approach. Biochem Pharmacol. 2013; 85:1234-45.

30. Soares J, Raimundo L, Pereira NA, Dos Santos DJ, Pérez M, Queiroz G, Leão M, Santos MM, Saraiva L. A tryptophanolderived oxazolopiperidone lactam is cytotoxic against tumors via inhibition of $\mathrm{p} 53$ interaction with murine double minute proteins. Pharmacol Res. 2015; 95-96C:42-52.

31. Bisio A, Nasti S, Jordan JJ, Gargiulo S, Pastorino L, Provenzani A, Quattrone A, Queirolo P, Bianchi-Scarrà G, Ghiorzo P, Inga A. Functional analysis of CDKN2A/ p16INK4a 50-UTR variants predisposing to melanoma. Hum Mol Genet. 2010; 19:1479-1491.

32. Lion M, Bisio A, Tebaldi T, De Sanctis V, Menendez D, Resnick MA, Ciribilli Y, Inga A. Interaction between p53 and estradiol pathways in transcriptional responses to chemotherapeutics. Cell Cycle. 2013; 12:1211-1224.

33. Labelle-Côté M, Dusseault J, Ismaïl S, Picard-Cloutier A, Siegel PM, Larose L. Nck2 promotes human melanoma cell proliferation, migration and invasion in vitro and primary melanoma-derived tumor growth in vivo. BMC Cancer. $2011 ; 11: 443$.

34. Fernandes JC, Borges M, Nascimento H, Bronze-da-Rocha E, Ramos OS, Pintado ME, Malcata FX, Santos-Silva A. Cytotoxicity and genotoxicity of chitooligosaccharides upon lymphocytes. Int J Biol Macromol. 2011; 49:433-438. 